\title{
Constitutions ANd Citizenship: Lessons for African Countries
}

\author{
John Mukum Mbaku' \\ Weber State University, Department of Economics, \\ Ogden, Utah, USA \\ jmbaku@weber.edu
}

\begin{abstract}
MBAKU, John, M. Constitutions and Citizenship: Lessons for African Countries. International and Comparative Law Review, 2017, vol. 17, no. 1, pp. 7-49. DOI 10.2478/iclr-2018-0001.
\end{abstract}

\begin{abstract}
Summary: Since the colonial period in Africa, ruling elites have manipulated laws regulating citizenship to advance their political and economic interests. The European colonialists used citizenship laws to enhance their ability to maintain control over the colonies and minimize the ability of Africans to fight for independence. Many Africans believed that independence and the establishment of new institutional arrangements would allow them to develop a common national citizenship, one in which all the citizens of each country would have equality before the law and be granted equal opportunity for self-actualization within all parts of the country, regardless of their racial or ethnic affiliation. However, in the post-independence period, incumbent political elites have been acting like their colonial counterparts and have used citizenship laws to get rid of critical and opposing voices by depriving these people of their nationality. In 1996, for example, Zambia's ruling political party, the Movement for Multi-Party Democracy (MMD), adopted a new constitution, which effectively stripped the country's independence president, Kenneth Kaunda, of his Zambian citizenship and prevented him from challenging the MMD for leadership of the country. Similarly, in 2000, then president of Côte d'Ivoire, Henri Konan Bédié, changed the constitution and introduced a citizenship clause that effectively disqualified the candidacy of his main opposition, Alassane Ouattara. South Africa's apartheid regime, on the other hand, introduced a raciallybased multilayered citizenship system in which individuals of European origin were placed at the top, enjoying full citizenship rights, and Africans were relegated to the bottom with extremely attenuated citizenship rights. Some African groups were actually forced to lose their South African citizenship. Citizenship is a complex issue and one that citizens of a country must deal with. The paper suggests that in doing so, African
\end{abstract}

1 John Mukum Mbaku is Brady Presidential Distinguished Professor of Economics \& John S. Hinckley Research Fellow at Weber State University (Ogden, Utah, USA). He is also a Nonresident Senior Fellow at the Brookings Institution, Washington, D.C., and an Attorney and Counselor at Law (licensed in the State of Utah). He received the J.D. degree and Graduate Certificate in Environmental and Natural Resources Law from the S.J. Quinney College of Law, University of Utah, where he was Managing Editor of the Utah Environmental Law Review, and a Ph.D. (economics) from the University of Georgia. This article reflects only the present considerations and views of the author, which should not be attributed to either Weber State University or the Brookings Institution. 
countries must not allow citizenship to be defined by race, ethnicity, religion, or other ascriptive traits, but by allegiance or fidelity to a set of values or ideals (e.g., democracy, rule of law, equality before the law) that define the nation.

Keywords: constitution, common citizenship, self-actualization, institutional arrangements, rule of law, peaceful coexistence, differentiated citizenship, ethnocultural diversity.

\section{General Introduction}

The manipulation of laws regulating citizenship for political purposes remains a major problem in many African countries, even after many decades of independence. ${ }^{2}$ Citizenship laws have been used by many incumbent African politicians to silence their critics ${ }^{3}$ and deprive their opponents of the opportunity to participate in political processes. ${ }^{4}$ In countries such as Tanzania, Botswana, and Swaziland, political elites have manipulated citizenship laws to deprive "political opponents and high profile media figures of nationality in attempts to get rid of their critical voices."

In 1996, the ruling political party in Zambia, the Movement for MultiParty Democracy (MMD), adopted a new constitution, ${ }^{6}$ which mandated that

2 Some of the most visible examples of the abuse of citizenship laws for political purposes come from Zambia. See, e.g., KOHN, Sebastian. Abusing Citizenship in Zambia-Again. Voices, Open Society Foundations. [online]. Available at: $<$ https://www.opensocietyfoundations.org/voices/abusing-citizenship-zambia-again> Accessed: 23 November 2016.

3 KOHN, supra note 2, p. 1.

4 For example, in Zambia in 1996, the ruling Movement for Multi-Party Democracy (MMD) party used laws on citizenship to deprive their major opponent, former president Kenneth Kaunda, of the opportunity to participate in the presidential election as a candidate for president. See KOHN, supra note 2. And, in 2000, then president of Côte d'Ivoire, Henri Konan Bédié changed the constitution and introduced a citizenship clause that effectively disqualified the candidacy of his main opposition, Alassane Ouattara. See Art. 35, Constitution de la République de Côte d'Ivoire du 23 juin 2000. [online]. Available at: $<$ http://democratie.francophonie.org/IMG/pdf/Cote_d_Ivoire.pdf > Accessed: 23 November 2016. Article 35 reads as follows: "Le candidat à lélection présidentielle doit être âgé de quarante ans au moins et de soixante quinze ans au plus. Il doit être ivoirien d'origine, né de père et de mère eux-mêmes ivoiriens d'origine." (Emphasis added). The controversial provision is in italics and it says: "He [i.e., the individual who is running for the position of President of the Republic of Côte d'Ivoire] must be of Ivorian origin, born of a father and of a mother who are themselves of Ivorian origin." Although Alassane Ouattara was born in Côte d'Ivoire, at least one of his parents was said to be of Burkinabè origin and hence, under Art. 35 of the Constitution of 2000, he was disqualified by the Ivorian Supreme Court as a candidate for the presidency. See FARAH, Douglas. Candidates Disqualified in Ivory Coast. The Washington Post, 7 October 2000. [online]. Available at: <https:// www.washingtonpost.com/archive/politics/2000/10/07/candidates-disqualified-in-ivorycoast/2cb35bf1-6647-473c-af3d-1441d6ab9172/> Accessed: 23 November 2016.

$5 \mathrm{KOHN}$, supra note 2, at 1.

6 Constitution of Zambia, 1996. [online]. Available at: <https://www.ilo.org/dyn/natlex/docs/ ELECTRONIC/26620/90492/F735047973/ZMB26620.pdf> Accessed: 18 August 2017. 
the mother and father of a presidential candidate must be Zambian by birth. According to Article 34(3)(a-b), "A person shall be qualified to be a candidate for election as President if - (a) he is a citizen of Zambia; (b) both his parents are Zambians by birth or descent." It was quite apparent to most Zambians at the time that the MMD's objective was to frustrate the candidacy of former president Kenneth Kaunda, ${ }^{8}$ the same person who had led the country to independence from Great Britain, and who at the time was challenging the MMD for leadership of the country.

The manipulation of citizenship laws to gain political and economic advantage is not limited to post-independence African states. During the colonial period in Africa, under many colonial rules, only peoples of European descent were granted full citizenship rights. For example, in French colonies, the Code de l'indigénat ${ }^{9}$ represented a set of laws which created an inferior legal status for Africans (les indigènes) and a much more progressive and robust one (which involved the enjoyment of full citizenship rights) to colonial inhabitants of European origin or those Africans who had evolved to the European cultural ideal and hence, were considered by colonial authorities to have been fully assimilated. ${ }^{10}$ Under this legal system, French citizenship was only granted to peoples of European origin and assimilated Africans (les assimilés) - these citizens enjoyed a lot of benefits, which included private property rights, especially in land, marriages that were recognized by the law, and perhaps, more importantly, exemptions from forced labor. ${ }^{11}$

7 Art. 34(3)(a-b), Constitution of Zambia, 1996, supra note 6.

8 Kenneth Kaunda was president of the Republic of Zambia from independence in 1964 (he assumed office on October 24, 1964) to November 2, 1991. He was succeeded by Frederick Chiluba of the MMD. See generally MUKWENA, Royson, SUMAILI, Fanuel (eds.). Zambia at Fifty Years: What Went Right, What Went Wrong and Wither to? A Treatise of the Country's Socio-Economic and Political Developments Since Independence. Gurgaon, India: Partridge Publishing, 2016 (examining, inter alia, the challenges of economic development in Zambia since independence under Kaunda and subsequent presidents).

9 See BUELL, Raymond Leslie. The Native Problem in Africa, Vol. 2. London, UK: Frank Cass, 1928 (examining, inter alia, the French indigénat system and its impact on political and economic developments in French colonies in Africa).

10 Regarding the application of the indigénat policy in the UN Trust Territory of Cameroons under French administration, see LeVINE, Victor T. The Cameroons: From Mandate to Independence. Berkeley and Los Angeles: The University of California Press, 1964.

11 See generally, MBAKU, John Mukum. Institutions and Development in Africa. Westport, Connecticut: Praeger, 2004 (examining, inter alia, France's assimilationist policies on political and economic developments in the French colonies in Africa); RUDIN, Harry Rudolph. Germans in the Cameroons, 1884-1914: A Case Study in Modern Imperialism. New Haven, Connecticut: Yale University Press, 1938 (examining, inter alia, the evolution of the German colony of Kamerun, which, like French colonies, had a legal system that created an inferior form of citizenship for Africans and a superior one for peoples of European descent); GIFFORD, P., LOUIS, William R. (eds.). France and Britain in Africa: Imperial Rivalry and Colonial Rule. New Haven, Connecticut: Yale University Press, 1971 (presenting a series of essays that explore the differences and similarities between French 
In apartheid South Africa, the white-dominated government used citizenship laws effectively to politically and economically marginalize groups that were designated by the political system as "nonwhite." ${ }^{2}$ In 1950, for example, the apartheid government, which had come into power in $1948,{ }^{13}$ enacted the Population Registration Act, ${ }^{14}$ which directed the government to compile a register of South Africa's population and issue each person an identity card. The new law identified the following categories of citizens or racial groups: White, Black (African, Native and/or Bantu), and Colored. The latter was further subdivided into Cape Malay, Griqua, Indian, Chinese, and Cape Colored..$^{15}$ This law, coupled with other laws, allowed the government to manipulate the concept of citizenship to discriminate against certain categories of people in both political and economic participation. For example, under apartheid laws, the majority black population was not allowed to participate in constitution making or the enactment of postconstitutional laws, including those that directly affected their lives ${ }^{16}$ The apartheid government subdivided the African population, which made up more than two-thirds of the country's population, into ten groups based mainly on linguistic lines and then assigned each group a "homeland" under what was referred to as the Bantustan policy. ${ }^{17}$ The apartheid government then proceeded to declare

and British colonial policies in Africa); SARRAUT, Albert. La mise en valeur des colonies françaises. Paris: Payot, 1923 (examining, inter alia, development policy in French colonies during the period 1914-1919) \& Thompson, Virginia, Adloff, Richard. French West Africa. Stanford, California: Stanford University Press, 1958 (examining, inter alia, French colonial policy in West Africa).

12 See generally FREDRICKSON, George M. White Supremacy: A Comparative Study in American and South African History. Oxford, UK: Oxford University Press, 1981 (examining, inter alia, South Africa's apartheid system and how it created various categories of citizenship for the various groups found in the country-white, African, and colored). See also COWEN, Denis Victor. The Foundations of Freedom: With Special Reference to Africa. Cape Town, South Africa: Oxford University Press, 1961, pp. 43-82 (examining, inter alia, constitution making in the colonies (Cape of Good Hope, Natal, Orange River Colony, and the Transvaal) that united in 1910 to form the Union of South Africa and showing how the discriminatory and non-inclusive approach to constitution making adopted by delegates representing the four colonies-Africans were not allowed to participate in the process-produced a constitution, the South Act (9 Edward VII, c.9)-which paved the way and provided the foundation for the establishment of the apartheid system in 1948). See also MBAKU, John Mukum. What Should Africans Expect from their Constitutions? Denver Journal of International Law \& Policy, 2013, vol. 41, no. 2, p. 160, fn 66.

13 See, e.g., DUBOW, Saul. Apartheid, 1948-1994. Cape Town: Oxford University Press, 2014 (providing a rigorous examination of racial discrimination in South Africa generally and under the apartheid regime in particular).

14 Parliament of South Africa. Population Registration Act No. 30 of 1950. [online]. Available at: <https://en.wikisource.org/wiki/Population_Registration_Act,_1950> Accessed: 23 November 2016.

15 See the Population Registration Act, supra note 14.

16 See, e.g., DUBOW, supra note 13 \& MBAKU, John Mukum. Institutions and Reform in Africa: The Public Choice Perspective. Westport, Connecticut: Praeger, 1997.

17 EGERÖ, Bertil. South Africa's Bantustans: From Dumping Grounds to Battlefronts. Upp- 
some of these homelands ${ }^{18}$ independent and sovereign countries, effectively and unilaterally depriving the "citizens" of these Bantustans of their South African citizenship. ${ }^{19}$

Long before the South African government began its systematic effort to abrogate the citizenship rights of African groups by creating so-called "homelands" or "bantustans" 20 and declaring these artificial creations independent states, it had already undertaken legislation to attenuate these rights and make it virtually impossible for African groups to function effectively as citizens within South Africa. One of the most important of these pieces of legislation was the collection of laws that was enacted by James Barry Munnik (JBM) Hertzog's Pact Government to create what came to be known as the "civilized labor policy." 21

sala: Nordiska Afrikainstitutet, 1991; SOUTH AFRICAN DEMOCRACY EDUCATION TRUST. The Road to Democracy in South Africa, 1970-1980. Pretoria, South Africa: Unisa Press, 2004 (both monographs examining, inter alia, how the so-called homelands, which were created by the apartheid government as a mechanism to deprive various South African ethnocultural groups of their South African citizenship, became the battlegrounds that actually contributed significantly to the demise of apartheid in the country).

18 These were (1) Transkei, (2) Bophuthatswana, (3) Venda, and (4) Ciskei. Once the apartheid government declared these bantustans independent states, their citizens effectively lost their South African citizenship and were now considered as "foreigners" in the land of their birth.

19 See, e.g., SOUTHALL, Roger. South Africa's Transkei: The Political Economy of an 'Independent' Bantustan. New York: Monthly Review Press, 1983; GOVERNMENT OF SOUTH AFRICA. Bophuthatswana at Independence: 6 December 1977. Pretoria, South Africa: Bureau for Economic Research re Bantu Development, 1977; LAHIFF, Edward, An Apartheid Oasis? Agricultural and Rural Livelihoods in Venda. London: Frank Cass, 2000; SWITZER, Les. Power and Resistance in an African Society: The Ciskei Xhosa and the Making of South Africa. Madison, Wisconsin: The University of Wisconsin Press, 1993. Africans who had been pushed into these "independent" homelands were no longer eligible to apply for South African passports and since none of the independent bantustans were granted diplomatic recognition by other countries (except South Africa), it meant that citizens of these homelands could not travel to other parts of the world using documents issued by their governments.

20 See generally BUTLER, Jeffrey, ROTBERG, Robert I., ADAMS, John. The Black Homelands of South Africa: The Political and Economic Development of Bophuthatswana and KwaZulu. Berkeley and Los Angeles: The University of California Press, 1978 (providing a rigorous examination of the history of two of apartheid-era's most important homelands).

21 Hertzog was South Africa's third prime minister. He came into office on June 30, 1924 and served until September 5, 1939. A lawyer by training (University of Amsterdam), he and his party, the National Party (NP), defeated Jan Smuts and the South African Party (SAP) in the election of 1924. Hertzog and the Afrikaner-dominated NP had formed an alliance with the South African Labor party, enabling them to win the 1924 election and form what came to be referred to as the Labor-Nationalist "Pact" Government. The new Pact government supported the principle of white supremacy and permanent nonwhite inferiority. This effective control of the South African government by white labor and Afrikaner farmers set the stage for massive and unrelenting state intervention in the labor market and produced the foundation for the apartheid state, which came into being in 1948. The legislative agenda ushered into South African political economy by the Pact Government had two 
The latter was made effective in South Africa through several pieces of legislation, the most important of which were the Industrial Conciliation Act No. 11 of 1924, the Wages Act No. 27 of 1925, and the Mines and Works Amendment Act No. 25 of 1926 - these laws, as argued by South African economist, Jill Natrass, ${ }^{22}$ "legally entrenched the concept of White labor supremacy" 23 in South Africa for many generations. The civilized labor policy effectively reserved certain skilled jobs in factories and the mines exclusively for whites and in the process, made it virtually impossible for Africans to exercise their full citizenship rights, especially in economic markets. ${ }^{24}$ This political and opportunistic manipulation of citizenship rights set the stage for the establishment of the apartheid system in South Africa in 1948, a system that lasted until $1994 .{ }^{25}$

major rungs-influx control laws; and color bar legislation. For a thorough examination of color bar legislation and how it affected political economy in South Africa, see generally NATTRASS, Jill. The South African Economy: Its Growth and Change. Cape Town: Oxford University Press, 1981; HUNTER, Guy (ed.). Industrialization and Race Relations: A Symposium. Westport, Connecticut: Greenwood, 1965; WILLIAMS, Walter E. South Africa's War Against Capitalism. Westport, Connecticut: Praeger, 1989; HUTT, William H. The Economics of the Color Bar. London: Institute of Economic Affairs, 1964; DOXEY, George V. The Industrial Color Bar in South Africa. Westport, Connecticut: Greenwood, 1961.

22 Nattrass, supra note 21.

23 Id. at 76.

24 For an overview of the civilized labor policy, see generally HUTT, supra note 21 and DOXEY, supra note 20. For a rent-seeking analysis of the civilized labor policy, see MBAKU, John Mukum. Property Rights and Rent Seeking in South Africa. Cato Journal, 1991, vol. 11, no. 1, pp. 135-150. The basic fear of Afrikaners, most of whom were primarily poor farmers, was that greater cooperation between "white capitalists" and "black workers" would relegate them to the economic periphery. However, instead of helping poor whites acquire necessary skills to become competitive in the labor market, Afrikaner leaders, with the help of the National Party (of South Africa), opted for government intervention, first, through the creation of the "civilized labor policy" (see, e.g., DOXEY, supra note 21) and the regulation of all forms of social interaction (e.g., the Prohibition of Mixed Marriages Act No. 55 of 1949, which banned all marriages between people of different races), and second, through the establishment of the apartheid system in 1948. Apartheid was determined to eliminate all forms of non-government sanctioned economic cooperation between the races, which Afrikaners feared could lead to greater social integration within South Africa. White farmers, the majority of whom were Afrikaners, saw the civilized labor policy and apartheid-era legislation, which strictly limited African access to industrial jobs, as creating a large pool of cheap labor, which they could utilize at minimum cost in their farming operations. For a public choice treatment of the relationship between "black" or "African" labor and agriculture in apartheid South Africa, see LOWENBERG, Anton D., KAEMPFER, William H. The Origins and Demise of South African Apartheid: A Public Choice Analysis. Ann Arbor, Michigan: The University of Michigan Press, 1998.

25 Despite the existence of a lot of legislative acts (collectively referred to as the "color bar" legislation (see, e.g., HUTT, supra note 21; DOXEY, supra note 21 \& WILLIAMS, supra note 21) that had effectively abrogated the rights of African groups to participate competitively in South Africa's labor market, Afrikaners and white labor, in the aftermath of World War II, were still convinced that profit-maximizing capital would, should the opportunity ever avail itself, opt for a colorblind labor market, one in which wages would be competitively determined without the interference or intervention of the government and race 


\section{Framing the Problem}

\subsection{Colonialism and Citizenship}

After the Europeans annexed or captured African territories, the next step was to establish institutions of social, economic, and political control. ${ }^{26}$ The overarching objective of the colonialist was to establish an institutional structure within the new colonies that would enhance the maximization of European objectives. ${ }^{27}$ Thus, economic, social and political development of the colony

would not function as an important determinant of access to employment opportunities. See, e.g., MBAKU, supra note 24, p. 148. White capital, many Afrikaners feared, would eventually push for the passage of legislation encouraging and enhancing closer intergroup relations and racial coexistence, a development which many whites, especially poor Afrikaners, believed would threaten their welfare. The existing system of property rights, which effectively rendered the citizenship of most African groups within South Africa economically nonviable-these groups were not allowed to engage fully in and benefit from economic activities-"could not be passed from generation to generation unless the strict separation of races was maintained." MBAKU, supra note 24, p. 148 . As argued by economist Mancur Olson, "the system could not possibly survive for many generations unless the demarcation between the races was preserved." OLSON, Mancur. The Rise and Decline of Nations: Economic Growth, Stagflation, and Social Rigidities. New Haven, Connecticut: Yale University Press, 1982, p. 164. Thus, when the Afrikaner-dominated National Party (of South Africa) returned to power in 1948, it pre-occupied itself with an aggressive legislative agenda that was designed to permanently render inoperable citizenship rights belonging to all African groups. The NP's most important policy was apartheid or separate development, which became official policy in South Africa in 1948. The NP ruled South Africa from June 4, 1948 until May 9, 1994. Although the last of the laws that sustained apartheid were abolished in 1991, apartheid's official end is regarded as coming with the democratic elections that took place in 1994 and formally established a nonracial democratic dispensation in the country. For a thorough examination of the demise of apartheid, see generally WALDMEIR, Patti. Anatomy of a Miracle: The End of Apartheid and the Birth of the New South Africa. New Brunswick, New Jersey: Rutgers University Press, 1998; SONNEBORN, Liz. The End of Apartheid in South Africa. New York: Chelsea House Publishers, 2010; CRUDEN, Alex, BRYFONSKI, Dedria. The End of Apartheid. Farmington Hills, Michigan: Greenhaven Press/Gale Cangage Learning, 2010; BRADLEY, Catherine. Causes and Consequences of the End of Apartheid. Austin, Texas: Raintree Steck-Vaughn, 1996; TAMES, Richard. The End of Apartheid: A New South Africa. London: Heinemann Library, 2001.

26 For a description of the procedures through which the British established political, economic, and social control over the territories that ultimately formed the colony of Nigeria in 1914, see generally BURNS, Sir Alan Cuthbert. History of Nigeria. London: G. Allen \& Unwin Ltd., 1963. The Germans, like the British, used similar procedures to establish control over territories on the Cameroon River District and eventually found the colony of Kamerun in 1884. See RUDIN, Harry R. Germans in the Cameroons, 1884-1914: A Case Study in Modern Imperialism. New Haven, Connecticut: Yale University Press, 1938.

27 These objectives included, inter alia, the flow of raw materials from the colonies to metropolitan factories and the development of the markets of the colonies for eventual reception of excess output from metropolitan industries. Lord Frederick Lugard, the architect of Britain's policy of indirect rule in West Africa and a colonial official of great distinction, stated that the colonies were important sources of primary commodities for Britain's 
would only be undertaken to the extent that such developments enhanced the maximization of the objectives of the Europeans resident in each colony ${ }^{28}$ and those in the home country.

But, how did these institutions of social, economic and political control affect citizenship? In virtually all these African colonies, the Europeans set up a dual legal system that created an inferior set of citizenship rights for Africans and a superior one for Europeans. Whether it was France's "l'assimilation coloniale," 29

domestic manufacturing industries and essential markets for excess output from these factories. See LUGARD, Lord Frederick. The Dual Mandate in Tropical Africa, 3d ed. London: W. Blackwood and Sons, 1926.

28 Note that in colonies where there were significant populations of European settlers (e.g., Algeria, Kenya, the four colonies that united in 1910 to form the Union of South Africa, the Rhodesias-Northern and Southern Rhodesia (now Zambia and Zimbabwe respectively), and South West Africa (now Nambia), the objectives of the Europeans resident in the colonies often conflicted with those of the métropole. In Natal, Cape of Good Hope, Orange Free Colony, and Transavaal, the four colonies that merged to become the Union of South Africa in 1910, there were regular conflicts between the British colonial government and the Afrikaners-European settlers of Dutch-German-French ancestry. These conflicts concerned many issues but the most important were property rights in land and the treatment of African or "native" tribes. Some of these disagreements resulted in wars between the British-dominated colonial government and the Afrikaners, such as the Anglo-Boer war of 1899-1902. See generally THOMAS, C. H. Origin of the Anglo-Boer War Revealed, 2nd ed. Fairford, Glos, UK: Echo Library, 2006 [1900]; SPIES, S. B. The Origins of the Anglo-Boer War. London: Edward Arnold, 1972.

29 France's policy of assimilation was the ideological basis of Paris' colonial policy in the 19th and 20th centuries. This policy, as officially propagated by French colonial officials, was designed to provide colonial "subjects" the opportunity to gain French citizenship by adopting French culture and language. Africans were also expected to abandon their traditional pursuits, such as hunting and gathering, and engage in "civilized pursuits," which included wage labor. The policy of assimilation was in line with many of the official justifications for colonialism, one of which was to "civilize" Africans by helping them "evolve" to the French/European cultural and linguistic ideal. The policy faced a lot of opposition in the colonies and was eventually downgraded to "association." For an introduction to the French policies of "assimilation" and "association," see BETTS, Raymond F. Assimilation and Association in French Colonial Theory, 1890-1914. Lincoln, Nebraska: The University of Nebraska Press, 1960; CROWDER, Michael. Senegal: A Study in French Assimilation Policy. New York City: Taylor \& Francis, 1962. 
Britain's "indirect rule," ${ }^{30}$ or Portugal's "assimilado,"31 these policies were designed to create inferior citizenship rights for the African populations of each colony and place the Europeans in a position to dominate Africans politically, economically, culturally, and socially. ${ }^{32}$

30 The British system of indirect rule was designed to allow colonial officials to control the colony and its inhabitants through pre-existing local (traditional) power structures. Traditional rulers were granted, by the colonial powers, the right and power to carry out dayto-day administrative, legal, and other duties. The traditional rulers were usually supervised or overseen by a European. The architect of Britain's indirect rule in Africa was Lord Lugard, who was also the High Commissioner of the Protectorate of Northern Nigeria from 1899 to 1906. The ideological underpinnings of the policy of indirect rule were not local self-government but the effective control of a large territory with huge populations by a small group of foreigners. Like other European colonial systems, indirect rule also created differential citizenship levels, with Africans, who were generally referred to as "natives" or "uncivilized races," being burdened with the most inferior form or category of citizenship. In fact, indirect rule created ethnocultural and racial cleavages in the colonies that outlasted colonialism and today, constitute a critical element in dysfunctional governance and a cause of the failure of many African countries to achieve the peaceful coexistence of their various population groups. See, e.g., CROWDER, Michael. Indirect Rule: French and British Style. Africa: Journal of the International African Institute, 1964, vol. 34, no. 3, pp. 197-205; DERRICK, Jonathan. The 'Native Clerk' in Colonial West Africa. African Affairs, 1983, vol. 82, no. 326, pp. 61-74; MAMDANI, Mahmood. Citizen and Subject: Contemporary Africa and the Legacy of Late Colonialism. Princeton, New Jersey: Princeton University Press. Mamdani's book is very important because it shows that both direct (France) and indirect (Britain) rule, as well as apartheid, were designed to achieve the same purpose-European despotism and permanent African political, economic, and social inferiority within the colonies. Direct rule abrogated the citizenship rights of Africans ("subjects" or "sujets") on racial grounds while indirect rule created a "customary" framework of governance that effectively abrogated the citizenship rights of subjects and granted Native Authorities appointed and sanctioned by the colonial state the right to define what constituted "custom" and hence, the types of citizenship rights that could be enjoyed by people who were not of European origin. It is important to note that evolved or assimilated Africans-that is, those "natives" who had achieved French of Portuguese citizenship-were not insulated from racial discrimination. The experiences of assimilationist Cameroonian scholar, Louis-Marie Pouka, are illustrative of the contradictions of French colonialism. He embraced assimilation but during his stay in France, he realized that the equality preached by proponents of assimilation was not part of daily life in the country. See BJORNSON, Richard. The African Quest for Freedom and Identity: Cameroonian Writing and the National Experience. Bloomington, Indiana: Indiana University Press, 1991. See also MAMDANI, id.

31 The Portuguese policy of "assimilado" was similar to France's policy of assimilation. Africans from the colony of Angola or Mozambique, for example, could qualify for "civilized" status and hence, achieve Portuguese citizenship and the rights attendant to it through education in Portuguese language and culture, as well as the abandonment of what were often referred to as "backward" or "uncivilized" practices and customs. See MENDY, Peter Karibe, LOBBAN, Richard A., Jr. Historical Dictionary of the Republic of Guinea-Bissau, 4th ed. Lanham, Maryland: Scarecrow Press, Inc., 2013. See also PERES, Phyllis. Transculturation and Resistance in Lusophone African Narrative. Gainesville, Florida: University Press of Florida, 1997.

32 See, e.g., MAMDANI, supra note 30. 
The purveyors of colonialism claimed that theirs was a civilizing mission, whose primary aim or objective was the extension of the fruits of technological advances (i.e., modernity) to what were often referred to as "backward races"implicit in this ideology was that the peoples of Africa, the Americas, and Asia, who were different from the Europeans, were culturally inferior and had to be civilized..$^{33}$ Viewed from this perspective, colonialism was simply a temporary activity, for, once the "uncivilized races" were civilized and fully assimilated, colonialism would lose its raison dêtre and would disappear. ${ }^{34}$

Colonialism, of course, was not a civilizing mission. For one thing, the peoples of these colonies did not need "civilizing." For another, the people who came to these colonies from Europe did not bring with them institutions that would have significantly improved the welfare of Africans. Instead, what the Europeans brought to the African colonies were institutions of plunder, cruelty, despotism, and exploitation. ${ }^{35}$ Europeans, argues Robert Fatton, Jr., a noted political scientist and expert on colonialism in Africa, imposed both themselves and their institutions on the African peoples and created within each colony, a political, economic, and social system that brought to the Africans many years of humiliation, degradation, and infantilization. ${ }^{36}$ In the process, Africans lost their right to live and function freely as citizens in their own lands.

Colonialism, contrary to its proponents, was never a benevolent mission designed to share technological advances with the peoples of Africa. ${ }^{37}$ Instead, it was a violent and insidious project designed specifically to subjugate Africans, abrogate their citizenship rights in their own lands, and enhance the ability of the Europeans to exploit Africans and their resources for the benefit of the metropolitan economies. ${ }^{38}$ As argued by Hugh E. Egerton, an expert on British imperial history, the "motives which prompted the European nations upon the field of

33 See FISCHNER-TINÉ, Harald, MANN, Michael (eds.). Colonialism as Civilizing Mission: Cultural Ideology in British India. London: Wimbledon Publishing Company (providing a rigorous analysis of the motives of British colonialism); CONKLIN, Alice L. A Mission to Civilize: The Republican Idea of Empire in France and West Africa, 1895-1930. Stanford, California: Stanford University Press, 1997 (arguing that despite its professed democratic values, the French Third Republic was still unable to resist the temptation to engage in an insidious and exploitative "civilizing" mission to Africa).

34 FISHER-TINÉ \& MANN, supra note 33.

35 See, e.g., FATTON, Robert, Jr. Liberal Democracy in Africa. Political Science Quarterly, 1990, vol. 105, no. 3, pp. 455-473.

36 FATTON, supra note 35, pp. 457-458.

37 MBAKU, John Mukum. Providing a Foundation for Wealth Creation and Development in Africa: The Role of the Rule of Law. Brooklyn Journal of International Law, 2013, vol. 38, no. 3, pp. 959-1051.

38 Egerton, a renowned expert on British imperial history, argues that an overarching objective of colonialism was the accumulation of wealth for the British people as a whole and for those Britons who ventured into the colonies as entrepreneurs. See EGERTON, Hugh E. Colonies and the Mercantile System, In NADEL, George H. CURTIS, Perry (eds.). Imperialism and Colonialism. London: Macmillan, 1969, pp. 57-66. 
colonization were in the main two, viz, the desire to win converts for the church, and the desire to win wealth for themselves." ${ }^{39}$ Lord Frederick Lugard, a distinguished British colonial officer and architect of Britain's indirect rule in Africa, opined that the colonies were critical sources of raw materials for industrial concerns in Britain and important markets for the sale of excess output from British industries. ${ }^{40}$

The British, like other European colonialists in Africa, did not plan to establish mutually beneficial relationships with Africans, those which would have prevented the various groups in each colony from being subjected to a degraded form of citizenship. For example, to win converts for their churches and create opportunities for their entrepreneurs to engage in profit-maximizing activities, the government of Great Britain could "have sought to establish diplomatic relations with various African kingdoms and states, with the latter allowed to maintain their independence. Once established, such inter-state relations, as they are today, would have allowed Christian missions to come to the African states and peacefully seek converts for their churches, and British entrepreneurs and traders would also have been able to seek opportunities to enter into mutually beneficial exchanges with their African counterparts." ${ }^{\text {41 }}$ Instead, Britain, like many other European countries, which at the time practiced "mercantilism," instead of "capitalism" as we understand it today, chose to engage in commercial practices that involved force (primarily violent conquest) and not mutually beneficial free exchange. In doing so, the British imposed on their colonies institutional arrangements that derogated the citizenship rights of the "native" populations and relegated these peoples to the political and economic periphery.

The argument that the European colonial powers never intended to engage in mutually beneficial arrangements with Africans is supported by pronouncements from important colonial officials of the 19th century, when the "scramble for Africa" ${ }^{\text {"42 }}$ was at its peak. For example, in 1841, then French Governor-General of Algeria, General Thomas Robert Bugead, declared that " $[w]$ henever the water supply is good and the land fertile, there we must place colonists ${ }^{43}$ without worrying about previous owners. We must distribute the lands [with] full title to the colonists." ${ }^{44}$ Earl Grey, a British colonial officer of considerable distinction,

39 EGERTON, supra note 38, p. 57.

40 LUGARD, supra note 27.

41 MBAKU, supra note 37, pp. 971-972.

42 For a discussion of how five European countries carved out African territory for themselves during the period 1880-1885, see generally PAKENHAM, Thomas. The Scramble for Africa. Boston, Massachusetts: Little, Brown, 2015 \& BETTS, Raymond F. The Scramble for Africa: Causes and Dimensions of Empire. Lexington, Massachusetts: Heath, 1972.

43 With respect to the African colonies, the "colonists" were Europeans who had settled in the colonies and intended to make the latter their permanent home. They were also referred to as "settlers" or, in the case of France, "les colons."

44 BRACE, Richard M. Morocco, Algeria, Tunisia. Englewood Cliffs, New Jersey: PrenticeHall, 1964, p. 48. 
summarized the feelings of his fellow settlers in southern Africa towards Africans or the "native tribes" as they were called when he declared that whenever and wherever there was conflict between British settlers and any African group, especially over land and water-use rights, the "facilities should be afforded the white [British] colonist for obtaining the possession of land theretofore occupied by Native tribes." 45

In virtually all European colonies, "Native tribes" were viewed by the colonizing population - the colonial officers, planters, missionaries, farmers, miners, and prospectors-as uncivilized peoples who needed to be civilized and saved from their "savage" and "uncivilized" ways. Missionaries saw these peoples as "lost souls" or "heathens" who needed to be converted to Christianity in order to guarantee them a place in Heaven. In their uncivilized stage, as judged by the colonialists, these Africans could not enjoy the same citizenship rights as the Europeans ${ }^{46}$ Nevertheless, as was the case in French and Portuguese colonies, if the Africans were willing and able and, did indeed, "assimilate"-converted to Christianity, accepted French (Portuguese) culture and language, and took a job of a European nature (e.g., wage employment, which implied the abandonment of their traditional and customary pursuits), they would be considered "evolved" enough to be granted French or Portuguese citizenship and could then become eligible to enjoy the same citizenship rights as their European counterparts. ${ }^{47}$

It is important to note that the scramble for Africa involved significant levels of force and violence and hence, it was inevitable that the laws and institutions that helped the Europeans achieve their goals in the continent would themselves be instruments of violence and oppression. Since the Europeans were determined to use the coercive apparatus of the state to effect the allocation of the resources of the colony, the institutions of law and order (e.g., the police force and the judiciary) evolved into instruments of violence to enhance the ability

45 Magubane, Bernard M. The Political Economy of Race and Class in South Africa. New York: Monthly Review Press, 1979, p. 71.

46 This reasoning was the basis of and foundation, for example, for the French policy of assimilation. See, e.g., BETTS, Raymond F. Assimilation and Association in French Colonial Theory, 1890-1914. Lincoln, Nebraska \& London, UK: University of Nebraska Press, 1960. Specifically, it was at the heart of the French Code de lindigénat, which created a special and inferior class of citizenship for the African inhabitants of the colonies and subjected them to activities (e.g., forced labor) that were considered inappropriate for civilized people (i.e., the Europeans).

47 This, of course, was the theoretical foundation of the assimilation policies in both French and Portuguese colonies. It was, however, not unusual for fully assimilated or evolved Africans to either lose their elevated citizenship rights or have them attenuated if they engaged in activities (such as joining anti-colonialism organizations) that were considered by the colonial government to be detrimental to the colonial enterprise. See, e.g., MBAKU, John Mukum. Cameroon, Republic of (République du Cameroun). In FALOLA, Toyin, JEANJACQUES, Daniel (eds.). Africa: An Encyclopedia of Culture and Society. San Francisco: ABC-CLIO, 2015, pp. 139-177. 
of the Europeans to subjugate Africans and effectively reduce them to "secondclass" citizenship status. ${ }^{48}$ This state of affairs was, of course, considered by the resident European population to be essential to their ability to maximize their objectives, which included the accumulation of wealth. Note, for example, the fact that during the apartheid period in South Africa, white/Afrikaner farmers preferred and sought a derogation of the citizenship rights of Africans in order to create a cheap "black" labor pool that could be exploited to the economic and financial advantage of these farmers. ${ }^{49}$

\subsection{Independence and the Hope for New Citizenship Rules}

Most Africans, especially those who were involved in the struggle for independence, believed that independence would grant them the opportunity "to rid themselves of not only the Europeans, but also of their laws and institutions and then, develop and adopt, through a democratic process-specifically, a peopledriven, bottom-up, participatory, and transparent institutional reform processinstitutional arrangements based on their own values, aspirations, traditions, and customs." ${ }^{50}$ These new institutional arrangements would allow Africans to develop a "common citizenship," one in which all the citizens of each country would have equality before the law and be granted equal opportunity for selfactualization within all parts of the country, regardless of their racial or ethnic affiliation. The hope was that the post-independence government would not create the multilayered, group-based or racially-based citizenship that was pervasive in many colonies throughout the continent. For, it was these multilayered citizenship arrangements that were used effectively by the European colonialists and colonists to oppress and infantilize Africans. ${ }^{51}$

48 See generally MBAKU, John Mukum \& KIMENYI, Mwangi S. Rent Seeking and Policing in Colonial Africa. The Indian Journal of Social Science, 1995, vol. 8, no. 3, pp. 277-306.

49 See, e.g., DOXEY, George V. The Industrial Color Bar in South Africa. Cape Town: Oxford University Press, 1961; HUTT, William H. The Economics of the Color Bar. London: The Institute of Economic Affairs, 1964; MAGUBANE, Bernard M. The Political Economy of Race and Class in South Africa. New York: Monthly Review Press, 1979.

50 MBAKU, John Mukum, IHONVBERE, Julius O. Introduction: Issues in Africa's "New" Global Era. In MBAKU, John Mukum, IHONVBERE, Julius O. (eds.). Transition to Democratic Governance in Africa: The Continuing Struggle. Westport, Connecticut: Praeger, 2003, p. 2.

51 One need only look at the way the French used the multilayered citizenship system in their colonies to maximize their interests (e.g., in addition to securing cheap labor for their economic activities, the French also used the indigénat system to provide labor for various activities in their homes, including cooking, cleaning, gardening, and taking care of children). For an elaboration of the indigénat system, see AUMONT-THIÈVILLE, Jacques. Du Régime de l'Indigénat en Algérie. Paris: Librairie Nouvelle de Droit et de Jurisprudence, 1906; MANIÈRE, Laurent. Le Code de l'Indigénat en Afrique occidentale française et son Application: le Cas du Dahomey (1887-1946). Paris: Thèse, Université Paris Diderot, 2007); MANN, Gregory. From Empires to NGOs in the West African Sahel: The Road to Nongovernmentality. Cambridge, UK: Cambridge University Press, 2015. In pre-1994 South Afri$\mathrm{ca}$, the Bantustan policy was effectively utilized to create a black labor pool from which 
The post-independence institutional arrangements were also supposed to fully and effectively constrain civil servants and politicians and prevent them from engaging in opportunistic manipulations of citizenship rules to their political advantage. In fact, the manipulation of citizenship rules, which has become quite common in many countries in the continent, has been used by many politicians to silence their competitors and critics, as well as enhance their ability to stay in office indefinitely. In Côte d'Ivoire, for example, the manipulation of citizenship rules actually prevented Alassane Ouattara from contesting the presidency of the country in $2000 .{ }^{52}$ In Zambia, the MMD political party used similar tactics to prevent the person who led Zambia to independence from contesting the presidency in $1996 .{ }^{53}$

What were the expectations of many Africans of their new governments? Put, another way, what did most Africans expect of their post-independence constitutions and institutions? Certainly, no African groups expected that the institutions of their new countries, like those of the colonial state, would be used to disenfranchise them, render their citizenship inoperable, and effectively relegate them to the political and economic periphery. In fact, the issues that gave impetus to the decolonization project included, inter alia, the relegation of African groups to an inferior form of citizenship that made it virtually impossible for them to participate gainfully in the economy, at least at levels of participation that were equivalent to those enjoyed by their European counterparts. For example, in a prepared speech made during his trial for treason before the Pretoria Supreme Court on April 20, 1964, ${ }^{54}$ Nelson Mandela argued that apartheid had created two types of citizenships in South Africa, one for whites and the other for Africans. He stated, inter alia, that South Africa is

a land of extremes and remarkable contrasts. The whites enjoy what may well be the highest standard of living in the world, whilst Africans

white (primarily Afrikaner) farmers could source cheap labor for their economic activities. See, e.g., FREDRICKSON, George M. White Supremacy: A Comparative Study of American and South African History. Cape Town: Oxford University Press, 1982.

52 See, e.g., HUMAN RIGHTS WATCH. Côte d'Ivoire: The New Racism, The Political Manuipulation of Ethnicity in Côte d'Ivoire. New York: Human Rights Watch, 2001; BRANCATI, Dawn. Democracy Protests: Origins, Features, and Significance. Cambridge, UK: Cambridge University Press, 2016; ANSORG, Nadine, KURTENBACH, Sabine (eds.). Institutional Reforms and Peacebuilding: Change, Path-Democracy and Societal Divisions in Post-War Communities. New York: Routledge, 2016.

53 ISIN, Engin F., NYERS, Peter (eds.). Routledge Handbook of Global Citizenship Studies. New York: Routledge, 2014; DeROCHE, Andy. Kenneth Kaunda, the United States and Southern Africa. New York: Bloomsbury Publishing, 2016; STEPANEK, Joseph F. Wringing Success from Failure in Late-Developing Countries: Lessons from the Field. Westport, Connecticut: Praeger, 1999.

54 MANDELA, Nelson. I am Prepared to Die: Nelson Mandela's Statement at the Opening of the Defense Case in the Rivonia Trial, Pretoria Supreme Court, April 20, 1964. [online]. Available at: <http://www.historyplace.com/speeches/mandela.htm > Accessed: 30 November 2016. 
live in poverty and misery. Forty percent of the Africans live in hopelessly overcrowded and, in some cases, drought-stricken Reserves, where soil erosion and the overworking of the soil makes it impossible for them to live properly off the land. Thirty percent are laborers, labor tenants, and squatters on white farms and work and live under conditions similar to those of the serfs of the Middle Ages. The other 30 percent live in towns where they have developed economic and social habits which bring them closer in many respects to white standards. Yet most Africans, even in this group, are impoverished by low incomes and high cost of living.

Mandela then went on to argue that his interest and that of the struggle of which he was a part, was not to dismantle apartheid, which was characterized by a multilayered citizenship system, with Africans at the bottom, and replace it with a new system, albeit also multilayered, in which Africans would be elevated to a higher citizenship level and whites would be placed at the bottom. Instead, he argued, he sought to eliminate both "white" and "black" domination and establish within South Africa, a system of equality based on a nonracial form of democracy. Within the society that Mandela envisioned for South Africa, there would only be one class of citizenship (i.e., a common supranational South African citizenship) and it would be available to all peoples, regardless of their race or ethnicity. ${ }^{55} \mathrm{He}$ declared as follows:

During my lifetime I have dedicated myself to this struggle of the African people. I have fought against white domination, and I have fought against black domination. I have cherished the ideal of a democratic and free society in which all persons live together in harmony and with equal opportunities. It is an ideal which I hope to live for and to achieve. But if needs be, it is an ideal for which I am prepared to die. ${ }^{56}$

In the post-apartheid South Africa envisioned by Mandela and his African National Congress colleagues, citizenship would be based, not on race, ethnicity, or some other ascriptive trait, but on a shared vision for peaceful coexistence of all groups, equality of opportunity for self-actualization, and a society undergirded by the rule of law. This approach to citizenship and government was made an important part of the foundation for South Africa's post-apartheid constitution. For example, South Africa's Interim Constitution of $1993^{57}$ contained 34

55 MANDELA, supra note 54 .

56 MANDELA, supra note 54.

57 In April 1993, the various parties that were negotiating an end to apartheid in South Africa and the subsequent construction of a new political, economic and social dispensation, restarted negotiations through an instrument that came be known as the Multi-Party Negotiating Process (MPNP). An MPNP committee suggested the development of a set of "constitutional principles" which would undergird the country's final and permanent constitution and which the latter had to comply with. The process was designed, inter alia, to make certain that many of the problems that had plagued the country in the past, which 
Political Principles with which the permanent constitution had to comply-for example, the first one states as follows: "I. The Constitution of South Africa shall provide for the establishment of one sovereign state, a common South African citizenship and a democratic system of government committed to achieving equality between men and women and people of all races." ${ }^{38}$

South Africans, informed by their experiences, especially with respect to citizenship, under the apartheid system, were quite concerned about how citizenship would be defined and practiced in the new post-apartheid South Africa. Hence, they took a particular interest in rights-based constitutionalism and made certain that those who were entrusted with the drafting of the country's permanent constitution had to be guided by certain critical constitutional principles-the latter enshrined in them important values that were of great interest and importance to South Africans, especially those who had been subjected to the indignities of apartheid. These values included, inter alia, "a common citizenship," "universal adult suffrage," "non-racialism," the protection of "all universally accepted fundamental rights, freedoms and liberties," and "equality before the law."59

Unfortunately, this careful and deliberative approach to constitution making, which the South Africans adopted during the reconstruction and reconstitution of the apartheid state and which allowed them to bring to the table discussions about the nature of citizenship, what it means and how it should be designed, was not adopted by other African countries during the process of constructing or designing their own constitutions..$^{60}$ During the decolonization and immediate post-independence periods, most African countries did not take constitu-

included the oppression of Africans by the white minority, would not re-occur and that the country would be able to develop and sustain a common South African citizenship, based not on race or ethnicity, but on shared ideals, which included equality before the law, peaceful coexistence, and equal opportunity for self-actualization. The MPNP proceeded to construct the Interim Constitution of 1993, which was eventually enacted into law by Parliament and came into force on April 27, 1994. See The Interim South African Constitution 1993. [online]. Available at: <http://www.sahistory.org.za/article/interim-southafrican-constitution-1993> Accessed: 1 December 2016.

58 Emphasis added. The Interim South African Constitution 1993, supra note 57.

59 CONSTITUTIONAL ASSEMBLY OF SOUTH AFRICA. Annual Report 1996. Cape Town: Constitutional Assembly of South Africa, 1996.

60 For a detailed analysis of the making of the permanent constitution of the post-apartheid South Africa, see generally SEGAL, Lauren, CORT, Sharon. One Law, One Nation: The Making of the South African Constitution. Auckland Park, South Africa: Jacana Media (Pty) Ltd., 2011; EBRAHIM, Hassen. The Soul of a Nation: Constitution-Making in South Africa. Cape Town: Oxford University Press, 1998; BELL, Paul. The Making of the Constitution: The Story of South Africa's Constitutional Assembly, May 1994 to December 1996. London: Churchill Murray Publications, 1997; STRAND, Per. Decisions on Democracy: The Politics of Constitution-Making in South Africa, 1990-1996. Uppsala: Uppsala University Press, 2000; GLOPPEN, Siri. South Africa: The Battle Over the Constitution. Aldershot, UK: Ashgate/Dartmouth, 1997. 
tion making seriously, nor did they consider constitutionalism and constitutions important and critical parts of post-independence governance. ${ }^{61}$

\subsection{Citizenship and Africa's Dysfunctional Decolonization Project}

The decolonization project in the African colonies was supposed to achieve certain objectives, the most important of which was to help the people and their emerging leaders fully transform the critical domains-the political, administrative, and judicial foundations of the state-and provide institutional arrangements that were capable of, at the minimum, (i) providing the wherewithal for the effective management of diversity and the promotion of the peaceful coexistence of all ethnocultural groups; and (ii) dealing fully with citizenship-citizenship rules had been manipulated during the colonial period to marginalize and oppress Africans and enhance the ability of the European colonialists and colonists to maximize their interests, which included the exploitation of Africans and their resources for the benefit of the Europeans. The hope was that, unlike the colonial period, the definition of citizenship and the rules governing it would be based on an effort to forge a common national citizenship for all peoples and not on race or ethnicity. ${ }^{62}$

In virtually all the African colonies, the decolonization project, the most important part of which was constitution making and the transformation of the critical domains, was dominated and controlled by three important groups, none of which was representative of the bulk of the African populations of each colony. These were (i) the colonial state, its political operatives and bureaucrats; (ii) the European entrepreneurial class, which consisted of traders/shop owners, planters, miners, and other commercial agents; and (iii) a relatively small group of highly educated and urban-based African elites, virtually all of whom had been educated in Europe, had lived and worked there for many years, and had fully adopted/accepted European cultures, customs, and values. ${ }^{63}$ Unfortunately for constitution making and state reconstruction in pre- and post-independence Africa, these three groups-colonialists, European entrepreneurs, and urbanbased indigenous elites-were not representative of the various population groups that inhabited each colony at independence. Of critical importance is the

61 See, e.g., MBAKU, John Mukum. What Should Africans Expect from Their Constitutions? Denver Journal of International Law \& Policy, 2013, vol. 41, no. 2, pp. 149-183.

62 See, e.g., MBAKU, supra note 61 \& MBAKU, John Mukum. Constitutionalism and Governance in Africa. In KALU, Kelechi A., SOYINKA-AIREWELE, Peyi (eds.). Socio-Political Scaffolding and the Construction of Change: Constitutionalism and Democratic Governance in Africa. Trenton, New Jersey: Africa World Press, pp. 40-41.

63 MBAKU, Constitutionalism and Governance, supra note 62, p. 41. In the case of some colonies, especially in sub-Saharan Africa, there was another player-European Christian missions, which as was the case in the UN Trust Territory of Cameroons under French administration, opposed populist indigenous political organizations, which they believed were seeking to establish socialism and other social systems that did not put the Christian God at the center of all governance systems. See generally LeVINE, infra note 66. 
fact that none of these three groups of people were elected by the relevant stakeholder groups within each colony to represent them in the process of designing and adopting institutional arrangements for the new countries that were emerging from colonial rule. ${ }^{64}$ Additionally, the urban-based elites who were supposedly representing the people at the constitution-making conferences were not well-informed about the "social, political and economic conditions then existing in most of the colony," ${ }^{35}$ nor were they aware of specific issues (e.g., peaceful coexistence, citizenship) that would have a significant impact on political economy in the post-independence state.

The usual procedure adopted by these three actors for constitution making was the imposition on the African peoples of institutional arrangements that did not reflect the people's values, interests, and customs and traditions. ${ }^{66}$ There was a general failure to fully consult and obtain the input of all relevant stakeholder groups within each colony during the constitution-making process. As a consequence, many critical issues, including citizenship, were never made part of constitutional discourse. ${ }^{67}$ That failure to consult and engage citizens in constitutional discourse meant that most people did not have the opportunity to examine and fully understand and appreciate the meaning of a "common citi-

64 MBAKU, John Mukum. Constitutionalism and the Transition to Democratic Governance in Africa. In MBAKU, John M., IHONVBERE, Julius O. (eds.). The Transition to Democratic Governance in Africa: The Continuing Struggle. Westport, Connecticut: Praeger, 2003, p. 109.

65 MBAKU, Constitutionalism and Governance, supra note 62, p. 41.

66 See, e.g., LeVINE, Victor T. The Cameroons: From Mandate to Independence. Berkeley and Los Angeles, California: The University of California Press, 1964 (examining, inter alia, constitution making in the UN Trust Territory of Cameroons under French administration and showing that the process of drafting the constitution for what would become the Republic of Cameroon (la République du Cameroun) after independence on January 1, 1960, was top-down, elite-driven, and non-participatory. The entire process was relegated to a non-representative committee that was influenced greatly by the colonial state, French commercial interests in the colony, French Christian missions, and a few urban-based indigenous elites.

67 For example, in the construction of the constitution that brought into being the Union of South Africa in 1910, only peoples of European origin - whites-were allowed to participate in constitution making. The majority African population was strictly excluded. This partly explains why subsequent South African governments were able to easily deprive Africans of their South African citizenship by creating bantustans, relocating various groups into them, and declaring these so-called homelands, independent states. For deliberations leading to the drafting and adoption of the South Africa Act (9 Edward VII, c.9), which essentially was the constitution that brought the Cape of Good Hope, Natal, the Transvaal, and the Orange River Colony to independence in 1910 as the Union of South Africa, see generally COWEN, Denis V. The Foundations of Freedom: With Special Reference to Southern Africa. Cape Town: Oxford University Press, 1961. In the French colonies, constitution making was dominated by the Charles de Gaulle's manipulations. For a critical analysis of the process, especially with respect to Guinea, which rejected de Gaulle's offer to remain a junior partner within the French Community, see SCHMIDT, Elizabeth. Cold War and Decolonization in Guinea, 1946-1958. Athens, Ohio: Ohio University Press, 2007. 
zenship" and how it was to be exercised. For example, despite the emergence of a new super structure called Nigeria, many people in the new country continued to identify primarily with their ethnocultural unit, only considering themselves as citizens of Nigeria when they needed something from the central government (e.g., an international passport to travel abroad).

In 1958, Charles de Gaulle and his Fifth French Republic offered the country's colonies in sub-Saharan Africa ${ }^{68}$ free association as autonomous republics within the French Community (Communauté française). Of all of France's colonies in sub-Saharan Africa, only Guinea, which considered the offer an attempt by France to force Guinean citizens to accept second-class citizenship within a community of nations controlled from Paris, rejected the offer and voted against the constitution. ${ }^{69}$ The colonies that voted in favor of the 1958 French Constitution effectively deprived their own citizens of the opportunity to engage in robust constitutional discourse and determine the nature of the institutions that were to govern them in the post-independence period. In doing so, they gave up robust discussions of various critical issues, including especially citizenship, as it related, for example, to the rights of individuals to travel freely within the country and to participate in political and economic markets in all parts of the country, regardless of ethnic origin and/or place of birth. ${ }^{70}$

The approach to constitution making adopted by France's colonies in subSaharan Africa ${ }^{71}$ was to forego robust constitutional discourse and simply adopt the model provided by the French Constitution of October 4, 1958. Many schol-

68 These colonies included UN Trust Territories, which technically were not colonies, but were nevertheless administered as colonies. These included what was generally referred to as "French Cameroons" and "French Togo," all of which were former German colonies but were ceded to the League of Nations after German defeat by Allied Forces during World War I and eventually became UN Trust Territories when the UN came into being in 1945. For French Cameroons, see LEVINE, Victor T. The Cameroons: From Mandate to Independence. Berkeley and Los Angeles, California: The University of California Press, 1964; for French Togo, see UNITED NATIONS. United Nations Visiting Mission to Trust Territories in West Africa: Report on Togoland under French Administration. New York City: United Nations, 1954; and for both territories, see RAUSCHNING, Dietrich, WIESBROCK, Katja, LAILACH, Martin. Key Resolutions of the United Nations General Assembly 1946-1996. Cambridge, UK: Cambridge University Press, 1997.

69 See SCHMIDT, supra note 67, pp. 162-163. This offer was made under the auspices of the French Constitution of October 4, 1958 (Constitution of the Fifth French Republic). The Guineans argued that the new arrangement offered them and other Africans by Charles de Gaulle and his Fifth Republic was nothing but a continuation of French colonialism. The Guineans decided to vote for independence and equality by rejecting de Gaulle's offer. Of all the Guineans who participated in the referendum, 1,136,324 (or 94\%) voted "Non" ("No") and 56,981 (4.7\%) voted "Oui" ("Yes). It was only Guinea that rejected the offer of association; in every other sub-Saharan African territory under French control, the 1958 constitution was approved by a significant majority-the exception was only Niger, where the "Oui" vote garnered only $75 \%$ of all the votes cast. Schmidt, id. at 168-169.

70 LeVINE, supra note 68, p. 187.

71 With the exception, of course, of Guinea. 
ars have criticized this approach to constitution making. In addition to the fact that it deprived citizens of the colonies of the opportunity to engage in serious and robust debate about various constitutional issues, including for example, the nature of the structure of post-independence government, citizenship (whether to define it through the constitution or by legislative acts), it also prevented them from reflecting fully on various concepts of governance (e.g., democracy and what it offered them, especially in the area of human rights, peaceful coexistence, the extent to which the state had to be constitutionally constrained in order to minimize government impunity, and human development). In criticizing the decision by the UN Trust Territory of Cameroons under French administration to vote yes to de Gaulle's constitution, political scientist and expert on constitutions and constitutionalism in Francophone Africa, Victor T. LeVine ${ }^{72}$ stated that although the Constitution of the French Fifth Republic was drafted "in the context of the constitutional crisis that brought De Gaulle to power" in France, the "circumstances surrounding the writing of the Cameroun ${ }^{73}$ constitution were not in any way analogous to those existing in France in 1958." ${ }^{\text {74 }}$

LeVine ${ }^{75}$ argues further that the constitutions of the former French colonies "created (i) national legislatures based on universal suffrage, (ii) legal and judicial systems resembling those of France, and (iii) governments nominally ratified by parliament, but in fact wholly responsible to the president. The resemblance to the French system was certainly more than nominal since the text of several of their constitutions, especially in sections dealing with the presidency, followed the French document almost word for word." ${ }^{36}$ What is critical for the purpose of the discussion in this paper is that by relying so much on foreign constitutional

72 LEVINE, supra note 68, p. 227.

73 "Cameroun" as used here refers to the UN Trust Territory of Cameroons under French administration, which gained independence on January 1, 1960 and took the name République du Cameroun (Republic of Cameroon). On October 1, 1961, the now independent République du Cameroun united with the UN Trust Territory of Southern Cameroons under British administration to found the Federal Republic of Cameroon. See UN, The United Nations and Decolonization, available at http://www.un.org/en/decolonization/selfdet.shtml (last visited on December 1, 2016).

74 LEVINE, supra note 68, p. 227.

75 LEVINE, supra note 68.

76 LEVINE, supra note 68, p. 184. Compare, for example, Article 5 in the Constitution of Cameroon, 1996 and the French Constitution of October 4, 1958. Article 5, French Constitution of 1958: "The President of the Republic shall ensure due respect for the Constitution. He shall ensure, by his arbitration, the proper functioning of the public authorities and the continuity of the State. He shall be the guarantor of national independence, territorial integrity and due respect for Treaties" (emphasis added). Article 5, Constitution of Cameroon, 1996: "The President of the Republic shall be the Head of State. Elected by the whole Nation, he shall be the symbol of national unity. He shall define the policy of the nation. He shall ensure respect for the Constitution. He shall, through his arbitration, ensure the proper functioning of public authorities. He shall be the guarantor of the independence of the Nation and of its territorial integrity, of the permanency and continuity of the State and the respect of international treaties and agreements" (emphasis added). 
models and foregoing a people-driven, inclusive and participatory constitutionmaking process, the African peoples were deprived of the opportunity to fully discuss critical issues, such as citizenship, that would later create many problems for them in the post-independence period.

What, then, is the problem with citizenship in Africa today? Although the issue of citizenship is an extremely complex one, three aspects of it are critical for political economy in the majority of African countries today. The first one is the failure of many countries on the continent to build a common national citizenship-as in, for example, a common Nigerian citizenship, defined not by ethnicity, religion or other ascriptive trait, but by allegiance to the concept of a Nigerian State characterized by fidelity to the rule of law, belief in peaceful coexistence of all groups, equality before the law, equal opportunity to engage in self-actualizing activities, etc. ${ }^{77}$ The second aspect of citizenship that is relevant to the discussion in this paper is the right of each citizen, regardless of their ethnic origin, to free internal exit-with the case of Nigeria, any citizen, regardless of whether they are Yoruba, Igbo, Hausa, or a member of one of the other more than 300 ethnocultural groups that inhabit the country, can migrate to any part of the country, readily establish residency there, and subsequently participate in all aspects of the economic, political and social life of that community. They can, for example, freely engage in entrepreneurial activities to create wealth for themselves without discrimination from so-called "indigenes" of the region or town or village. In other words, in terms of rights, duties, immunities, and privileges, citizenship must prevail over the country's entire territory, without regard to where within the country the citizen was born or where his or her ancestors were born. ${ }^{78}$ Finally, citizenship must not be used as a tool to marginalize political opponents or prevent certain individuals from participating fully in the political life of the country, including standing for elections to important positions in government. ${ }^{79}$

77 See, e.g., TAIWO, Olufemi. Of Citizens and Citizenship. In AKIBÁ, Okon. Constitutionalism and Society in Africa. Aldershot, UK: Ashgate, 2004, p. 55.

78 TAIWO, supra note 77.

79 This issue was alluded to earlier when we examined how some African political elites (including the Afrikaner-dominated regime that came to power in South Africa in 1926 and 1948) have manipulated citizenship rules to marginalize their opponents, disenfranchise various groups of citizens, and create institutional environments in which they can continue to dominate political economy for many years. See, e.g., DORMAN, Sara, HAMMETT, Daniel, NUGENT, Paul (eds.). Making Nations, Creating Strangers: States and Citizenship in Africa. Leiden, The Netherlands: Brill, 2007 (examining, inter alia, how citizenship is defined in many African countries and how political elites in these countries have often manipulated citizenship rules to marginalize the political opposition and enhance the ability of the incumbent regime to remain in power indefinitely). See also MANBY, Bronwen. Citizenship Law in Africa: A Comparative Study. New York City, USA: Open Society Foundations/African Minds, 2016 (examining laws and practices governing citizenship in African countries and indicating that many of these laws are often arbitrary, discriminatory, contradictory, and designed to allow the government to engage in various 
In the rest of this paper, we examine these issues and make recommendations on how African countries can engage their citizens in robust national dialogue to confront these issues and build constitutional safeguards that enhance the construction of a common citizenship and minimize the opportunities for governments to manipulate laws and institutions governing citizenship either to marginalize their political opponents, disenfranchise them and prevent them from participating in governance, or make it difficult for citizens to travel freely throughout the country and establish residency in any part of the country that they desire. But first, we must revisit the concept of differentiated citizenship and see how it impacts nation building.

\section{Differentiated Citizenship and Nation Building in Africa}

\subsection{Introduction}

During the colonial period in Africa, there was a lot of intolerance and prejudice (i.e., discrimination based on skin color, as well as on religion). ${ }^{80}$ Although a significant level of the exploitation and discrimination that occurred in the colonies was orchestrated by the Europeans - colonialists and colonists-and directed at indigenous African groups, intergroup conflicts, some of them related to or caused by historical prejudice, were quite common. ${ }^{81}$ Many of Africa's foresighted pre-independence nationalists, specifically those like Ruben Um Nyobé (of the former German colony of Kamerun) ${ }^{82}$ and the Gold Coast's Kwame Nkrumah, ${ }^{83}$ sought to establish, in the postcolony, institutional arrangements that enhanced the effective management of ethnocultural diversity and provided the wherewithal for peaceful coexistence of all of their countries' diverse population groups. ${ }^{84}$

forms of impunity and marginalize groups that oppose government policies).

80 The French indigénat system was just one example of the way European colonialists restructured colonial institutions to provide themselves with the wherewithal to exploit, infantilize, and discriminate against Africans. See, e.g., CROWDER, Michael. West Africa under Colonial Rule. Evanston, Illinois, USA: Northwestern University Press, 1968; CROWDER, Michael. Colonial West Africa: Collected Essays. New York City, USA: Routledge, 1978.

81 In the 1860s, for example, there were regular wars fought between ethnocultural groups along the Bights of Biafra and Guinea over control of trade routes-for example, in April 1865, 700 Ikorodu warriors participated in a fight against the Egba for control of trade routes. See BURNS, Sir Alan Cuthbert. History of Nigeria. London: G. Allen \& Unwin Ltd., 1963, pp. 134-136. See also TAMUNO, Tekena N. The Police in Modern Nigeria 1861-1965: Origins, Development and Role. Ibadan, Nigeria: The University of Ibadan Press, 1970, p. 18 and RUDIN, Harry Rudolph. Germans in the Cameroons 1884-1914: A Case Study in Modern Imperialism. New Haven, Connecticut, USA: Yale University Press, 1938.

82 See, e.g., JOSEPH, Richard A. Radical Nationalism in Cameroun: Social Origins of the U.P.C. Rebellion. London: Clarendon Press, 1977.

83 See, e.g., BINEY, Ama. The Political and Social Thought of Kwame Nkrumah. New York City, USA: Palgrave Macmillan, 2011.

84 Nelson Mandela, South Africa's first post-apartheid president, preached a similar philoso- 
In today's modern democratic countries, especially those such as Canada and the United States, which are characterized by significant levels of ethnocultural diversity, constitutional provisions have been used to provide the tools and the wherewithal to manage diversity. For example, through the Bill of Rights, the United States Constitution has provided protections for the fundamental rights of all citizens ${ }^{85}$ Canada has provided its peoples with similar constitutional protections. ${ }^{86}$ The management of diversity in Canada and the United States has also involved granting citizens certain freedoms, including freedom of association and of speech and mobility (including especially the right to move freely throughout the country and freely engage in exchange and contract), as well as the right to form political organizations (e.g., political parties) and participate in their respective countries' political life. ${ }^{87}$

With respect to Canada, Kymlicka ${ }^{88}$ has argued that while "the protection provided by these common rights of citizenship is sufficient for many of

phy. During his trial for treason before the Pretoria Supreme Court on April 20, 1964, he made clear that his intention and that of his compatriots in the African National Congress was to dismantle apartheid and create a new society in which all persons, regardless of their racial background or the ethnocultural group to which they belonged, would enjoy equality before the law and be granted the right of self-actualization. See MANDELA, Nelson. Nelson Mandela: I am Prepared to Die: Nelson Mandela's Statement at the Opening of the Defense Case in the Rivonia Trial, Pretoria Supreme Court, April 20, 1964. [online]. Available at: <http://www.historyplace.com/speeches/mandela.htm> Accessed: 30 November 2016.

85 See generally JUDSON, Karen. The Constitution of the United States. Berkeley Heights, New Jersey, USA: Enslow Publishers, Inc., 2013. Note, however, that the people of African origin in the United States were not granted equal treatment before the law until Amendments 13 (Abolition of Slavery) and 14 (Civil Rights) to the U.S. Constitution. See HALBROOK, Stephen P. Freedmen, The Fourteenth Amendment and the Right to Bear Arms, 1866-1876. Westport, Connecticut: Praeger, 1998; GOLDSTONE, Lawrence. Inherently Unequal: The Betrayal of Equal Rights by the Supreme Court, 1865-1903. New York City: Bloomsbury Publishing, 2011; OAKES, James. Freedom National: The Destruction of Slavery in the United States, 1861-1865. New York City: W. W. Norton and Company, Inc., 2013; VORENBERG, Michael. Final Freedom: The Civil War, the Abolition of Slavery, and the Thirteenth Amendment. Cambridge, UK: Cambridge University Press, 2001.

86 See generally CONTE, Alex, BURCHILL, Richard. Defining Civil and Political Rights: The Jurisprudence of the United Nations Human Rights Committee. New York City: Routledge, 2013; FORSYTHE, David P. (ed.). The United States and Human Rights: Looking Inward and Outward. Omaha, Nebraska, USA: The University of Nebraska Press, 2000; MATTHEWS, Robert O., PRATT, Cranford (eds.). Human Rights in Canadian Foreign Policy. Kingston, Ontario \& Montreal, Quebec: McGill-Queen's University Press, 1988.

87 See, e.g., KROPF, Martha E. Institutions and the Right to Vote in America. New York City: Palgrave Macmillan, 2016 (examining, inter alia, how U.S. institutions of democracy have affected the rights of citizens and their ability to participate in politics at various levels of government). See also SANCTON, Andrew, ZHENMING, Sancton (eds.). Citizen Participation at the Local Level in China and Canada. Boca Raton, Florida: CRC Press, 2015 (examining, inter alia, citizenship participation in local politics in Canada and China).

88 KYMLICKA, Will. Three Forms of Group-Differentiated Citizenship in Canada. In Benhabib, Seyla (ed.). Democracy and Difference: Contesting Boundaries of the Political. Prince- 
the legitimate forms of diversity in society," ${ }^{\prime 9}$ other forms of difference can be accommodated only through special legal or constitutional pressures, above and beyond the common rights of citizenship." ${ }^{\prime 9}$ Kymlicka goes on to argue that certain types of diversity can only be managed effectively if citizens are granted what is referred to as "differentiated citizenship."

In the study of diversity in Africa, it is important to recognize the fact that many of today's African countries are actually multination states-the formation of these states has involved the bringing together of various distinct groups or nations, each with its own customs and culture, as well as laws and institutions. For example, the Republic of Cameroon can be described as consisting of a "federation" of Anglophones and Francophones or a confederation of several ethnocultural kingdoms (e.g., Nso', Bamoun, Bangwa, Mankon, Bali-Nyonga, $\mathrm{Oku}$, just to name a few). Before the arrival of the colonialists, who engaged in determined efforts to dissolve many of these kingdoms, they were actual nations in the "sociological sense of being historical communities, institutionally complete, occupying a given territory or homeland, and sharing a distinct language and history." 92 Many of today's African countries are made up of several "nations" and hence, can be considered as "multination states."

The process of colonization of African territories involved the bringing together, through force, of various ethnocultural groups to form single political and economic units, which the Europeans could more effectively control and exploit. ${ }^{94}$ These units were officially referred to as colonies-in the post-independence period, these units, wholly or with some modifications, would become independent states. For example, the German colony of Kamerun, which came

ton, New Jersey: Princeton University Press, p. 153.

89 KYMLICKA, supra note 88, p. 153.

90 KYMLICKA, supra note 88, p. 153.

91 KYMLICKA, supra note 88, p. 153. See also YOUNG, Iris Marion. Justice and the Politics of Difference. Princeton, New Jersey: Princeton University Press, 1990 (examining, inter alia, various theories of justice, with special emphasis on the treatment of minorities in the United States-women, African Americans, American Indians, as well as gays and lesbians).

92 KYMLICKA, supra note 88, pp. 153-154.

93 See generally MOLTCHANOVA, Anna. National Self-Determination and Justice in Multinational States. New York City: Springer, 2009 (examining, inter alia, self-determination by subgroups within "multination" or "multinational" states); MACLVER, Don (ed.). The Politics of Multinational States. New York City: Palgrave Mcmillan, 2016 (examining, inter alia, the problems that ethnic pluralism presents to the governance of "multinational states").

94 See, e.g., MBAKU, John Mukum, KIMENYI, Mwangi S. Rent Seeking and Policing in Colonial Africa. Indian Journal of Social Science, 1995, vol. 8, no. 3, 1995, pp. 277-306 (discussing, inter alia, the founding of the British colony of Nigeria). 
into being in $1884,{ }^{95}$ included parts of present-day Gabon, Republic of Congo, Republic of Cameroon, Nigeria, Central African Republic, and Chad. ${ }^{96}$

Many developed countries that are "multinational" (e.g., Canada) have tried to deal with the problems of governance by adopting a federalist form of government. Several scholars have argued that if a "different balance of power had existed [during the founding of what is now a federated Canada], it is possible that Aboriginals and French-Canadians would have retained their original sovereignty, rather than being incorporated into the larger Canadian federation." 97 A similar claim can be made about present-day Nigeria, which came into being through the amalgamation of the Colony and Protectorate of Southern Nigeria and the Northern Nigerian Protectorate. ${ }^{98}$ As is evident by the continued struggle between various cleavages in Nigeria either for control of the central government in Abuja or for secession to form their own sovereign states, ${ }^{99}$ had a different balance of power existed during the colonial period, many of the ethnocultural groups that the colonialists had forcefully brought together to form the colony of Nigeria in 1914, would have preferred to retain their sovereignty and remain independent polities. ${ }^{100}$ In colonial Kamerun, ${ }^{101}$ several well-established

95 See generally RUDIN, Harry Rudolph. Germans in the Cameroons, 1884-1914: A Case Study in Modern Imperialism. New Haven, Connecticut: Yale University Press, 1938 (examining, inter alia, the founding of the German colony of Kamerun on the Cameroon River District in 1884).

96 RUDIN, supra note 95.

97 KYMLICKA, supra note 88, p. 154.

98 BURNS, Sir Alan Cuthbert. History of Nigeria. London: G. Allen \& Unwin Ltd., 1963.

99 Since independence in 1960, the predominantly Christian southern Nigeria has fought the predominantly Muslim north for control of the country. From January 6, 1967 to January 15,1970 , various ethnocultural groups in the eastern part of the country waged war to secede from the federation and form their own country called Republic of Biafra. For an overview of struggle of Igbos and other ethnocultural groups to found the Republic of Biafra, see generally UZOKWE, Alfred Obiora. Surviving Biafra: The Story of the Nigerian Civil War: Over Two Million Died. Lincoln, Nebraska: iUniverse, 2003; AWOLOWO, Obafemi. Awo on the Nigerian Civil War. London: J. West Publications, 1982; MOMOH, H. B. The Nigerian Civil War, 1967-1970: History and Reminiscences. London: Sam Bookman Publishers, 2000; AZIKIWE, Nnamdi. Peace Proposals for Ending the Nigerian Civil War. London: Colusco Limited, 1969; UWECHUE, Ralph. Reflections on the Nigerian Civil War: A Call for Realism. London: O.I.T.H. International Publishers Limited, 1969.

100 For example, the struggle of the Idoma people of Nigeria against British colonial rule is well-known. See, e.g., ANYEBE, A. P. Man of Courage and Character: The Ogbuloko War in Colonial Idomaland of Nigeria. Enugu, Nigeria: Fourth Dimension Publishers, 2002.

101 "Kamerun" was the name of the German colony that was founded on the Cameroon River District in 1884. Kamerun was captured by Allied Expeditionary Forces during World War I and was subsequently divided into League of Nations mandates and, after World War II, UN Trust Territories, under British and French administrations. See generally RUDIN, supra note 94; NGOH, Victor Julius. History of Cameroon since 1800. Limbe, Cameroon: Presbook, 1996; ARDENER, Edwin, ARDENER, Shirley (eds.). Kingdom on Mount Cameroon: Studies in the History of the Cameroon Coast, 1500-1970. Providence, Rhode Island \& London, UK: Berghahn Books, 1996. 
kingdoms waged wars against the European colonialists in an attempt to retain their sovereignty. For example, the Bakweri fought the Germans to retain their political and economic autonomy and the Bamoun fought the French to safeguard their culture, language, religion, and governance institutions. ${ }^{102}$

\subsection{Groups Reject Assimilation as Road to Nation-Building: The Case of the} Anglophones of Cameroon

Many countries in Africa, including, for example, Cameroon and Nigeria, are not only "multination" states, but they are also polyethnic states. ${ }^{103}$ Since reunification in 1961, ${ }^{104}$ Cameroonians, whose official languages are English and French, have suffered from an identity crisis. ${ }^{105}$ Although unification between the UN Trust Territory of Southern Cameroons under British administration and the République du Cameroun in 1961 was expected to produce a constitutional federation consisting of relatively autonomous states, what emerged, how-

102 See generally MBAKU, John Mukum. Culture and Customs of Cameroon. Westport, Connecticut: Greenwood Press, 2005; Rudin, supra note 95; DeLANCEY, Mark Dike, MBUH, Rebecca Neh, DeLANCEY, Mark W. Historical Dictionary of the Republic of Cameroon. Lanham, Maryland: The Scarecrow Press, Inc., 2010; LOUMPET-GALITZINE, Alexandra. Njoya et le Royaume Bamoun: Les Archives de la Société des Missions Évangéliques de Paris, 1917-1937. Paris: Éditions Karthala, 2006.

103 A polyethnic state is one that consists of several ethnocultural or ethnic groups. Such "divided" countries pose significant challenges for governance. For a review of the challenges faced by polyethnic states, see generally SHWEDER, Richard, MINOW, Martha, MARKUS, Hazel Rose (eds.). Engaging Cultural Differences: The Multicultural Challenge in Liberal Democracies. New York City: Russell Sage Foundation, 2002; BHAMRA, Meena K. The Challenges of Justice in Diverse Societies: Constitutionalism and Pluralism. New York: Routledge, 2016; CHENG, Lucie. Immigrant Integration in a Polyethnic Society. Honolulu, Hawaii: University of Hawaii Press, 1971.

104 Out of the German colony of Kamerun emerged the UN Trust Territories of Southern and Northern Cameroons under British administration and the UN Trust Territory of Cameroons under French administration. In 1961, plebiscites were held in the Britishadministered territories-British Northern Cameroons chose to gain independence by joining the independent Federation of Nigeria and British Southern Cameroons opted to join the independent République du Cameroun (the former UN Trust Territory of Cameroons under French administration, which had gained independence on January 1,1960). Unification between République du Cameroun and the UN Trust Territory of Southern Cameroons took place on October 1, 1961. For more on the reunification between the two sections of the former German colony, see PERCIVAL, John. The 1961 Cameroon Plebiscite: Choice or Betrayal. Bamenda, Cameroon: Langaa Research \& Publishing CIG, 2008; NGOH, Victor Julius. Cameroon: From Federal to Unitary State, 1961-1972. Limbe, Cameroon: Design House, 2004; NDI, Anthony. Southern West Cameroon Revisited (1950-1972) Vol. 1: Unveiling Inescapable Traps. Bamenda, Cameroon: Langaa Research \& Publishing CIG, 2014.

105 For a critical analysis of some of the identity-related issues in post-unification Cameroon, see generally ATANGA, Mufor. The Anglophone Cameroon Predicament. Bamenda, Cameroon: Langaa Research \& Publishing CIG, 2011; KONINGS, Piet, NYAMNJOH, Francis B. Negotiating an Anglophone Identity: A Study of the Politics of Recognition and Representation in Cameroon. Leiden, The Netherlands: Brill, 2003. 
ever, was a political and economic entity that was dominated and controlled by the more numerous Francophones. ${ }^{106}$ Even before the federation was unitarily abolished by the Ahmadou Ahidjo ${ }^{107}$ government in 1972, ${ }^{108}$ Anglophones had already begun to complain of political and economic marginalization. ${ }^{109}$

As a consequence of the political and economic domination of the country by the Francophones, a lot of Anglophones tried to improve their chances of surviving and, perhaps, flourishing, in this new country, by assimilating to the French cultural ideal-in addition to learning French and proceeding to communicate, especially in public, exclusively in French, many of them either adopted French spellings for their names ("Ndoumbe'" instead of "Ndumbe") or French versions of their names (e.g., "Philémon" instead of "Philemon").

However, beginning in the early-1990s, many Anglophones who had embraced assimilation as a survival technique within this francophone-dominated political and economic entity, began to openly and expressly reject that assimilationist approach to nation building and call for a constitutional model that would grant them the power to retain their heritage (e.g., the common law,

106 At the time of unification, the former British-governed territory, which took the name West Cameroon in the new federation, accounted for about 9 percent of the total land area and 20 percent of the population of the federation. See JOHNSON, Willard R. The Cameroon Federation: Political Integration in a Fragmentary Society. Princeton, New Jersey: Princeton University Press, 2015, p. ix.

107 Ahmadou Ahidjo was the first president of the Federal Republic of Cameroon. He ruled the country from 1961 to 1982, when he retired and was succeeded by his prime minister, Paul Biya, who remains the President of the Republic of Cameroon to this day (2017). For an examination of the complaints of Anglophones about their marginalization at the hands of the Francophones, see, e.g., MBANASO, Michael U., KORIEH, Chima J. (eds.). Minorities and the State in Africa. Amherst, New York: Cambria, 2010.

108 On May 20, 1972, the Ahidjo government abolished the federation and opted for a unitary state. The country's name was changed from Federal Republic of Cameroon to United Republic of Cameroon. See, e.g., MBAKU, John Mukum. Culture and Customs of Cameroon. Westport, Connecticut: Greenwood Press, 2005, p. 34 \& MBAKU, John Mukum. Judicial Independence, Constitutionalism and Governance in Cameroon: Lessons from French Constitutional Practice. European Journal of Comparative Law and Governance, 2014, vol. 1, no. 4, p. 360.

109 Shortly after unification and formation of a federation, the Ahidjo government issued decree No. 61-DF-15 and divided the country into administrative regions and assigned a "federal inspector" to each region-the federal inspector was accountable to the federal president. The new law made West Cameroon (the English-speaking part of the country) one of six political regions and unconstitutionally abrogated the federated State's political and economic autonomy as provided for in the unification constitution (the 1961 Constitution). See, e.g., EBUNE, Joseph B. The Dilemma of the Federal System in West Cameroon, 1961-1972. Journal of Scientific Research and Studies, 2016, vol. 3, no. 7, pp. 133-145. [online]. Available at: <http://www.modernrespub.org/jsrs/content/2016/July. htm > Accessed: 22 August 2017; MBAKU, John Mukum. Cameroon's Stalled Transition to Democratic Governance: Lessons from Africa's New Democrats. African and Asian Studies, 2002, vol. 1, no. 3, p. 135. 
English language, and the highly decentralized form of government)-that is, allow them to exercise their right of self-determination. ${ }^{110}$ Nevertheless, Anglophones who were agitating for a change in the country's institutional structure were split into two groups: (1) those who were demanding restoration of the federation and the federated state model, which would allow the Anglophones to retain their institutions and maintain the type of political and economic autonomy that had been granted them by the federal constitution of $1961 ;{ }^{111}$ and (2) those Anglophone activists who sought a total and complete disengagement from the Republic of Cameroon and the formation of a sovereign and independent state with an internationally recognized character. ${ }^{112}$

Cameroon is not the only country in which some ethnocultural groups have rejected the assimilationist approach to nation-building ${ }^{113}$ and are opting for an institutional model that enhances the ability of each group to retain certain aspects of its ethnic or cultural heritage and still remain part of a vibrant and viable nation-state. Thus, according to this system of polyethnicity, although all groups work towards national integration and the building of a single, unified nation, the institutional arrangements also allow each group to maximize its own unique values. ${ }^{114}$ Cameroon's Anglophones argue that those of them who insist on using English as their main medium of communication should not be con-

110 MBAKU, supra note 109.

111 Some Anglophone "constitutional federalists" saw the 1961 federal constitution as incapable of guaranteeing the type of autonomy that they sought. Hence, while they supported a return to federalism, they wanted new constitutional dialogue that would allow them to craft a more federalist constitution, one that would more effectively guarantee their rights and freedoms. See, e.g., MBAKU, supra note 109.

112 See generally NFOR, Nfor N. In Chains for My Country: Crusading for the British Southern Cameroons. Bamenda, Cameroon: Langaa Research \& Publishing CIG, 2014; ANYANGWE, Carlson. Imperialistic Politics in Cameroun: Resistance \& the Inception of the Restoration of the Statehood of Southern Cameroons. Bamenda, Cameroon: Langaa Research \& Publishing CIG, 2008.

113 The assimilationist approach to nation-building seeks to eliminate all cultural identities and create a nation-state in which there is one single identity. See, e.g., KYMLICKA, W. Three Forms of Group-Differentiated Citizenship in Canada. In BENHABIB, S. (ed.). Democracy and Difference: Contesting Boundaries of the Political. Princeton, New Jersey: Princeton University Press, 1996, p. 153.

114 These values include culture and customs, language, religion, and certain traditions. In Cameroon, for example, several Anglophone groups have argued that the national constitution should be changed to allow them to have more control over issues of language, education (especially at the primary and secondary levels), and legal structure-the Anglophones want to retain the common law, which was inherited from the British. See generally ANYANGWE, Carlson. Criminal Law in Cameroon: Specific Offences. Bamenda, Cameroon: Langaa Research \& Publishing CIG, 2011; PALMER, Vernon Valentine (ed.). Mixed Jurisdictions Worldwide: The Third Legal Family. Cambridge, UK: Cambridge University Press, 2012; ENONCHONG, Henry Ndifor Abi. Cameroon Constitutional Law: Federalism in a Mixed Common-Law and Civil-Law System. Yaoundé, Cameroon: Centre dédition et de production de manuels et d'auxilaires de l'enseignement, 1967. 
sidered unpatriotic or less nationalistic than their Francophone counterparts, nor should the Bamoun, or the Widekum, or the Bamiléké who want to retain several of their cultural and customary practices be forced to abandon them in order to remain loyal Cameroonians.

Most countries in Africa are multinational and polyethnic, partly due to colonial conquest and forced amalgamation of the conquered nations into single political and economic units that came to be known as colonies. ${ }^{15}$ In countries such as Nigeria, some of these "nations" are demanding that their governments grant them the right of self-determination, which they claim was abrogated through colonial consolidation and other post-independence political manipulations. ${ }^{116}$ Like the Québécois in Canada, some ethnocultural groups in Nigeria are demanding "certain powers of self-government," ${ }^{117}$ which they argue, they never relinquished or gave up when they were forcefully incorporated into what came to be called the colony of Nigeria - the latter would subsequently become the independent Federal Republic of Nigeria.

In recent years in Nigeria, the extremist group called Boko Haram has been engaged in a violent and destructive campaign to transform northern Nigeria into an Islamic State. Nevertheless, before Boko Haram began its violent revolt, many Muslim leaders, especially in the northern states, had already been demanding the imposition of various Islamic institutions (e.g., Sharia law) on their communities. ${ }^{118}$

\section{Self-Government Rights and Polyethnic Rights: Are They a Threat to a Common Citizenship?}

In writing about the rights of minority groups in Canada, Kymlicka ${ }^{119}$ distinguishes between "self-government rights" and "polyethnic rights."120 He argues

115 See, e.g., RUDIN, Harry Rudolph. The Germans in the Cameroons, 1884-1914: A Case Study in Modern Imperialism. New Haven, Connecticut: Yale University Press, 1938 (examining, inter alia, the amalgamation of several ethnocultural groups to form the German colony of Kamerun in 1884).

116 See, e.g., BEREKETEAB, Redie (ed.). Self-Determination and Secession in Africa: The Post-Colonial State. New York City: Routledge, 2014; WEISBAND, Edward, THOMAS, Courtney I. P. Political Culture and the Making of Modern Nation-States. New York City: Routledge; OFFODILE, Chudi. The Politics of Biafra and the Future of Nigeria. Morrisville, North Carolina: Lulu Publishing Services, 2016.

117 KYMLICKA, W. Three Forms of Group-Differentiated Citizenship in Canada. In BENHABIB, S. (ed.). Democracy and Difference: Contesting Boundaries of the Political. Princeton, New Jersey: Princeton University Press, 1996, p. 155.

118 See, e.g., LAREMONT, Ricardo R. Islamic Law and Politics in Northern Nigeria. Trenton, New Jersey: Africa World Press, 2011 \& KENDHAMMER, B. Muslims Talking Politics: Framing Islam, Democracy, and Law in Northern Nigeria. Chicago, Illinois: The University of Chicago Press, 2016.

119 KYMLICKA, supra note 117.

120 KYMLICKA, supra note 117, p. 156. 
that "[1]ike self-government rights, [polyethnic] rights are not seen as temporary, because the cultural differences they protect are not something we seek to eliminate." ${ }^{121} \mathrm{He}$ states further, however, that "unlike self-government rights, polyethnic rights are usually intended to promote integration into the larger society, not self-government." 122 Viewed from this perspective, one can conclude that polyethnic rights are more likely than self-government rights to promote nation building and the development of a "common national citizenship"-while the various ethnocultural groups would still be able to maintain their unique cultural practices, they would be able to do so as citizens of a larger community called the "nation." 123

Within many African countries, various groups have been advocating for self-government rights, as well as for polyethnic rights. First, some groups do not want to assimilate and integrate into their existing polities and, as a consequence, they do not demand either self-government rights or polyethnic rights. Instead, they want to secede and form their own independent and sovereign polity with an internationally recognized identity - this is the desire of some Anglophone activists in Cameroon, ${ }^{124}$ who do not want to integrate into the predominantly Francophone Republic of Cameroon. They desire, instead, to resurrect the now defunct UN Trust Territory of Southern Cameroons under British administration and transform it into an independent and sovereign nation. Anglophone Cameroon's secessionists no longer want to remain citizens of a francophonedominated country-they seek citizenship in a new country. ${ }^{125}$

121 KYMLICKA, supra note 117, p. 156.

122 KYMLICKA, supra note 117, pp. 156-157.

123 Within the United States, for example, one can find many ethnocultural groups that have retained their cultural and customary practices but consider themselves full citizens of the United States. Occasionally, however, conflicts have arisen between these cultural practices and U.S. laws. See generally GRILLO, Ralph, et al. (eds.). Legal Practice and Cultural Diversity. New York City: Routledge, 2009 (examining, inter alia, how contemporary cultural and religious diversity affects and challenges legal practice in the United States); NORGREN, Jill, NANDA, Serena. American Cultural Pluralism and Law. Westport, Connecticut: Praeger, 2006 (examining, inter alia, the challenges posed U.S. law by the practices of various cultural groups within the country).

124 One of the most important secessionist groups in Cameroon is the Southern Cameroons National Council (SCNC). For more information on the SCNC, see, e.g., LEVINE, Victor T. Politics in Francophone Africa. Boulder, Colorado: Lynne Rienner, 2004, p. 117; SHELLEY, Fred M. Nation Shapes: The Story Behind the World's Borders. San Francisco, California: ABC-CLIO, 2013, p. 268.

125 In recent years, the Government of Cameroon under Paul Biya has used laws designed to fight the Boko Haram insurgency to make it much more difficult for those fighting for the independence of the Anglophone regions (North West Region and South West Region) of Cameroon to openly promote the cause of independence. See, e.g., MBOM, Sixtus. New Anti-Terrorism Law Batters Cameroonians Seeking Secession. Inter Press Service News Agency, April 26, 2015. [online]. Available at: <http://www.ipsnews.net/2015/04/new-antiterrorism-law-batters-cameroonians-seeking-secession/> Accessed: 4 January 2017. 
Second, other groups are willing to remain within their existing polities, work towards a mild form of national integration and nation building, with the understanding that existing institutional arrangements would be reconstituted or transformed to provide them with the right of self-government. Like the Québécois in Canada, these ethnocultural African groups want a federal form of government in which they can have significant jurisdiction over issues that are important to the maintenance of their cultural identity. This is the desire of some Anglophone activists (i.e., the so-called "federalists") in Cameroon, as well as that of many ethnocultural groups in other African countries (e.g., the Zulus in South Africa; the Oromo of Ethiopia, although some Oromo activists actually prefer a "greater-Oromo-nation" that brings together the Oromo from Ethiopia, Kenya, and Somalia to form an independent nation, separate from present-day Ethiopia, and Kenya, Somalia-this latter group seeks to give up their Ethiopian citizenship and acquire citizenship in a new Oromo nation; and the Igbo of Nigeria). ${ }^{126}$

As exemplified by the Greater Somalia movement in the Horn of Africa, many ethnic "nations" whose members are found in more than one country (e.g., Somali of Ethiopia, Somalia, Kenya and Djibouti; and the Yoruba of Nigeria \& Benin Republic) have, at varying times, campaigned and advocated for the establishment of a new, independent and sovereign polity encompassing all their members from the nations in which they currently reside. ${ }^{127}$ Supporters of these so-called "greater ethnic nations" have argued that the scattering of the peoples of these "ethnic nations" was a result of the events that made up the Berlin Conference (1884-1885), which set the stage for the arbitrary and artificial partition of the continent and the forceful resettlement of members of various ethnic groups in two or more countries. For example, as argued by the supporters of a Greater Somalia nation, the colonization of the Horn of Africa (i.e., the Somali Peninsula) and the eventual drawing of boundaries by various European

126 For Oromo, see generally ETEFA, Tsega. Integration and Peace in East Africa: A History of the Oromo Nation. New York City: Palgrave Macmillan, 2012 \& KEFALE, Asnake. Federalism and Ethnic Conflict in Ethiopia: A Comparative Regional Study. New York City: Routledge, 2013; Zulus, see ROBINS, Steven L. From Revolution to Rights in South Africa: Social Movements, NGOs \& Popular Politics after Apartheid. Suffolk, UK and Rochester, New York: James Currey, 2008; Igbos, see ODURUKWE, Ikechukwu. A New Dawn, Biafra, Our Right to Self-Determination, Freedom and the Future. Bloomington, Indiana: AuthorHouse, 2010 \& WEISBAND, Edward, THOMAS, Courtney I. P. Political Culture and the Making of Modern Nation-States. New York City: Routledge, 2015, p. 174.

127 On the Yoruba generally, see FALOLA, Tonyi, AKINYEMI, Akintunde (eds.). Encyclopedia of the Yoruba. Bloomington, Indiana: Indiana University Press, 2016 \& OYEBADE, Adebayo (ed.). The Foundations of Nigeria: Essays in Honor of Toyin Falola. Trenton, New Jersey: Africa World Press, 2003; on Greater Somalia, see WEDEMAN, Nicholas Blakely. Ethnicity and Territorial Conflict in Greater Somalia: Irredentism Reconsidered. Madison, Wisconsin: University of Wisconsin Press, 1989 \& THOMPSON, Vincent Bakpetu. Conflict in the Horn of Africa: The Kenya-Somalia Border Problem 1941-2014. Lanham, Maryland: University Press of America, 2015. 
countries destroyed the Somali nation and scattered its citizens into what are today four independent countries-Kenya, Ethiopia, Djibouti, and Somalia. The Somali people, it is argued, have the right to self-determination by reconstituting that state, which was destroyed by colonialism. ${ }^{128}$

Finally, similar to the treatment of minorities in Canada, some individuals and groups who advocate on behalf of ethnocultural groups in Africa have argued that rather than look only at secession or self-government within existing polities, it might be possible to create "special representation rights" for these groups-through such a process, government and governance can be made to fully and effectively reflect the diversity of each country-whether diversity is based on language (as in Cameroon), ethnicity (as is the case in many countries in the continent), or on religion.

Under the "special representation rights" approach, there would be one common citizenship but certain political rights would be granted minority groups. For example, a certain number of seats in the upper legislative chamber (i.e., the Senate) would be reserved for members of heretofore marginalized and deprived groups. Representation in the lower house, however, would be based on population. The evidence from many countries in Africa shows that many minority ethnocultural groups, either due to their remote (and relatively inaccessible) geographic location within the country, or their failure to acquire skills in the "official language" of the country (English in the former British colonies; French in the former French and Belgian colonies, etc.), their extremely high levels of poverty and material deprivation, or other impediments (e.g., deliberate policy by the government, such as Jim Crow laws in the Southern United States, which effectively deprived African Americans from fully participating in economic and political markets, and apartheid laws in pre-1994 South Africa,

128 See, e.g., CARMENT, David, James, Patrick, TAYDAS, Zeynep. Who Intervenes? Ethnic Conflict and Interstate Crisis. Columbus, Ohio: The Ohio State University Press, 2006 (see, especially, Chapter 4) \& KIMENYI, Mwangi S. Ethnic Diversity, Liberty and the State: The African Dilemma. Cheltenham, UK: Edward Elgar, 1997, who argues that institutional reforms involving decentralization and federalism are more effective in the management and accommodation of ethnic diversity in African countries. He argues further that it may be necessary, in some cases, to redraw existing national boundaries and create completely new nations from existing ones. This is what was done through the Comprehensive Peace Agreement (2005), which created the conditions for the emergence of South Sudan. An independent and sovereign South Sudan was created out of territory previously considered part of the Republic of Sudan. See generally LERICHE, Matthew, ARNOLD, Matthew. South Sudan: From Revolution to Independence. Oxford, UK: Oxford University Press, 2013; JOHNSON, Hilde F. South Sudan: The Untold Story from Independence to the Civil War. New York City: I. B. Tauris \& Co. Limited, 2016; ROLANDSEN, Øystein H., DALY, M. W. A History of South Sudan: From Slavery to Independence. Cambridge, UK: Cambridge University Press, 2016; GRAWERT, Elke (ed.). After the Comprehensive Peace Agreement in Sudan. Suffolk, UK: James Currey, 2010; GARANG, John. The Genius of Dr. John Garang: Speeches on the Comprehensive Peace Agreement (CPA). New York: CreateSpace Independent Publishing Platform, 2015. 
which imposed similar constraints on the participation of the country's black majority in governance), have generally been underrepresented in the legislature and other public decision-making bodies. Thus, it is argued, there is urgent need in these countries to find ways to guarantee the representation of these groups in political decision-making. ${ }^{129}$

Since independence, many African countries have undertaken constitutional reforms or amendments, supposedly in an effort to deal with issues of the representation of minorities in government. Unfortunately, virtually all of these institutional reforms have been elite-driven, top-down, non-participatory, and not representative enough to include many of the marginalized peoples and groups. In addition to the fact that these reforms have usually been controlled by a small group of urban-based political elites, there was never any effort to fully and effectively consult all relevant stakeholder groups and seek their input before engaging in the process of reconstructing and reconstituting national institutional arrangements. ${ }^{130}$ As a consequence, these reforms have failed to produce mechanisms to enhance more participation, by minority subcultures, in political systems.

The overarching issue in Africa today is citizenship and how each African country can develop a common national citizenship for all its diverse groupswhether the groups are defined according to ethnicity (e.g., the Igbos, Yorubas, and Fulani in Nigeria), language (the Anglophones and Francophones in Cameroon), or religion (the Muslims and Christians in Nigeria). The most effective way to secure such a common national citizenship is to engage all relevant

129 See generally MBANASO, Michael U., KORIEH, Chima J. (eds.). Minorities and the State in Africa. Amherst, New York: Cambria Press, 2010; DERSSO, Solomon (ed.). Perspectives on the Rights of Minorities and Indigenous Peoples in Africa. Pretoria, South Africa: Pretoria University Law Press, 2010; ADAM, Michael (ed.). Indian Africa: Minorities of Indian-Pakistani Origin in Eastern Africa. Nairobi, Kenya: Mkuki na Nyota Publishers, 2015; EWUMBUE-MONONO, Churchill. Indigenouos Minorities and the Future of Good Governance in Cameroon: An Inquiry into the Politics of Local Governance in the Local Councils of Fako Division, 1866-2001. Buea, Cameroon: Center for Research in Democracy and Development in Africa, 2001; SUBERU, Rotimi T. Ethnic Minority Conflicts and Governance in Nigeria. Nairobi, Kenya: Institut Français de Recherche en Afrique, 1999; GHANEA, Nazila, XANTHAKI, Alexandra (eds.). Minorities, Peoples and Self-Determination: Essays in Honor of Patrick Thornberry. Leiden, The Netherlands: Brill, 2005.

130 See generally MBAKU, John Mukum. Institutions and Reform in Africa: The Public Choice Perspective. Westport, Connecticut: Praeger, 1997 (examining, inter alia, the failure of many African countries to engage in democratic (i.e., bottom-up, inclusive, participatory, people-driven) constitution-making processes. Many of these countries, have over the years, preferred top-down, elite-driven, non-democratic approaches to constitution making and institutional reforms. Contrast these experiences with that of South Africa in 1993-1994, which is considered relatively democratic and inclusive. On South Africa, see SEGAL, Lauren, CORT, Sharon. One Law, One Nation: The Making of the South African Constitution. Auckland Park, South Africa: Jacana, 2011. 
stakeholder groups in inclusive and participatory constitution making to produce laws that define citizenship based on allegiance to the same values (e.g., democracy, rule of law, equality before the law) that define the nation, as well as minimize the ability of ruling elites to manipulate the laws to marginalize their political opponents and/or get rid of critical and opposing voices.

\section{Conclusion}

After more than sixty years of independence, many countries in Africa have still not yet been able to find ways to prevent the manipulation, by ruling elites and their supporters, of national constitutions for political advantage. As a consequence, many politicians continue to use the constitution-amendment process to enhance their ability to monopolize political power. ${ }^{131}$ This problem arises, partly, from the fact that many countries in the continent have yet to entrench the concept of a common citizenship in both their constitutions and their political discourse.

In countries, such as Canada and the United States, that are characterized by significant levels of ethnocultural diversity, constitutional provisions have been utilized effectively to provide the necessary tools to manage and deal with this diversity. For example, through the Bill of Rights, the U.S. Constitution has provided protection of the fundamental rights of all citizens, regardless of their racial, national, or ethnic origins. Canada has provided its diverse peoples with similar protections. However, it is important to note that the inclusion of a Bill of Rights in a country's constitution is a necessary but not sufficient condition for the effective protection of fundamental rights. Sufficiency requires a governing process undergirded by a separation of powers with effective checks and balances-that is, one that effectively prevents ruling elites from engaging in various forms of opportunism (e.g., manipulating the constitution to discredit political opponents).

Africans expected independence to offer them the opportunity to create, through a participatory and inclusive process, governance processes that reflected their values, ideals, worldview, and aspirations. Perhaps, more importantly

131 Examples include Henri Konan Bédié, who in 1995 changed the electoral code to eliminate the political candidacy of his most important political rival, Alassance Ouattara, from competing for the presidency of Côte d'Ivoire. See FRINDÉTHIÉ, K. Martial. From Lumumba to Gbagbo: Africa in the Eddy of the Euro-American Quest for Exceptionalism. Jefferson, North Carolina: McFarland \& Company, 2016; HELLWEG, Joseph. Hunting the Ethical State: The Benkadi Movement of Côte d'Ivoire. Chicago, Illinois: The University of Chicago Press, 2011. Also, Frederick Chiluba, who in 1996, changed the Constitution of Zambia to prevent the country's former president, Kenneth Kaunda, from qualifying as a candidate for the presidency. See generally WILKINSON, Michael (ed.). Global Pentecostal Movements: Migration, Mission, and Public Religion. Leiden, The Netherlands: Brill, 2012 \& MNGOMEZULU, B. Richard (eds.). The President for Life Pandemic in Africa: Kenya, Zimbabwe, Nigeria, Zambia and Malawi. London: Adonis \& Abbey Publishers, Limited, 2013. 
was the fact that Africans were expected to use the constitution-making process to deal fully with the issue of citizenship - the hope was that each country would create a common citizenship, based not on race, religion, or ethnicity, but on the belief in or fidelity to a set of values or ideals, which were elaborated in the constitution and which would define the nation. Of course, the new institutional arrangements were also expected to adequately constrain post-independence civil servants and political elites and prevent them from engaging in any form of political opportunism. Unfortunately, constitution making in most of the African colonies was top-down, elite-driven, and non-participatory. As a consequence, issues of importance to the various ethnocultural groups that live in these countries, such as citizenship, were not fully examined by the people. It is for this reason that citizenship remains a highly contested issue in virtually all these countries. For example, in addition to the fact that presidents in many African countries have been able to easily manipulate laws regulating citizenship to gain advantage over their political rivals, many citizens are unable to fully utilize their citizenship within their own countries. In fact, it is often the case, for example, that Nigerians of various ethnocultural groups are not able to travel freely throughout the country and establish residency in any part of the country that they desire. Such efforts are often rebuffed by people who consider themselves indigenes to the area or so-called "native sons" or "sons of the soil."132

While there is an urgent need for Africans to revisit national laws regulating citizenship in order to provide themselves with an effective common supranational citizenship, and, in addition, enhance the ability of all citizens to fully understand and appreciate the concept of citizenship, the process through which this is carried out must be robust and participatory, allowing for all relevant stakeholder groups to participate. Without such an inclusive and participatory process, the outcome is not likely to be accepted and respected by the majority of the people and groups in these countries.

\section{References}

ADAM, Michael (ed.). Indian Africa: Minorities of Indian-Pakistani Origin in East Africa. Nairobi, Kenya: Mkuki na Nyota Publishers, 2015.

ANSORG, Nadine, KURTENBACH, Sabine (eds.). Institutional Reforms and Peacebuilding: Change, Path-Democracy and Societal Divisions in Post-War Communities. New York City: Routledge, 2016.

ANYANGWE, Carlson. Imperialistic Politics in Cameroun: Resistance \& Inception of the Restoration of the Statehood of Southern Cameroons. Bamenda, Cameroon: Langaa Research \& Publishing CIG, 2008

ANYANGWE, Carlson. Criminal Law in Cameroon: Specific Offenses. Bamenda, Cam-

132 See IGWE, Obasi. Nigeria: The New Socialist Manifesto: With Some Lessons for Other African and Third World Countries. Lagos, Nigeria: Emancipation Press, 1989. Also see TAIWO, Olufemi. Of Citizens and Citizenship. In AKIBA, Okon (ed.). Constitutionalism and Society in Africa. Aldershot, UK: Ashgate, 2004, pp. 55-78. 
eroon: Langaa Research \& Publishing CIG, 2011.

ANYEBE, A. P. Man of Courage and Character: The Ogbuloko War in Colonial Idomaland of Nigeria. Enugu, Nigeria: Fourth Dimension Publishers, 2002.

ARDENER, Edwin, ARDENER, Shirley. (eds.). Kingdom on Mount Cameroon: Studies in the Hsitory of the Cameroon Coast, 1500-1970. Providence, Rhode Island \& London, UK: Berghahn Books, 1996.

ATANGA, Mufor. The Anglophone Cameroon Predicament. Bamenda, Cameroon: Langaa Research \& Publishing CIG, 2011.

AUMONT-THIÈVILlE, Jacques. Du Régime de l'Indigénat en Algérie. Paris: Lbrairie Nouvelle de Droit et de Jurisprudence, 1906.

AWOLOWO, Obafemi. Awo on the Nigerian Civil War. London, UK: J. West Publications, 1982.

AZIKIWE, Nnamdi. Peace Proposals for Ending the Nigerian Civil War. London, UK: Colusco Limited, 1969.

BELL, Paul. The Making of the Constitution: The Story of South Africa's Constitutional Assembly, May 1994 to December 1996. London: Churchill Murray Publications, 1997.

BEREKETEAB, Redie (ed.). Self-Determination and Secession in Africa: The Post-Colonial State. New York City: Routledge, 2014.

BETTS, Raymond F. Assimilation and Association in French Colonial Theory, 1890-1914. Lincoln, Nebraska: The University of Nebraska Press, 1960.

BETTS, Raymond F. The Scramble for Africa: Causes and Dimensions of Empire. Lexington, Massachusetts: Heath, 1972.

BHAMRA, Meena K. The Challenges of Justice in Diverse Societies: Constitutionalism and Pluralism. New York City: Routledge, 2016.

BINEY, Ama. The Political and Social Thought of Kwame Nkrumah. New York City: Palgrave Macmillan, 2011.

BRANCATI, Dawn. Democracy Protests: Origins, Features, and Significance. Cambridge, UK: Cambridge University Press, 2016.

BRJORNSON, Richard. The African Quest for Freedom and Identity: Cameroonian Writing and the National Experience. Bloomington, Indiana: Indiana University Press, 1991.

BRACE, Richard M. Morocco, Algeria, Tunisia. Englewood Cliffs, New Jersey: PrenticeHall, 1964.

BRADLEY, Catherine. Causes and Consequences of the End of Apartheid. Austin, Texas: Raintree Steck-Vaughn, 1996.

BURNS, Sir Alan Cuthbert. History of Nigeria. London, UK: G. Allen \& Unwin Ltd., 1963.

BUTLER, Jeffrey, ROTBERG, Robert I., ADAMS, John. The Black Homelands of South Africa: The Political and Economic Development of Bophuthatswana and KwaZulu. Berkeley and Los Angeles: The University of California Press, 1978.

CARMENT, David, JAMES, Patrick, TAYDAS, Zeynep. Who Intervenes? Ethnic Conflict and Interstate Crisis. Columbus, Ohio: The Ohio State University Press, 2006.

CHENG, Lucie. Immigrant Integration in a Polyethnic Society. Honolulu, Hawaii: University of Hawaii Press, 1971.

CONKLIN, Alice L. A Mission to Civilize: The Republican Idea of Empire in France and West Africa, 1895-1930. Stanford, California: Stanford University Press, 1997.

CONSTITUTIONAL ASSEMBLY OF SOUTH AFRICA. Annual Report, 1996. Cape Town, South Africa: Constitutional Assembly, 1996.

CONTE, Alex, BURCHILL, Richard. Defining Civil and Political Rights: The Jurisprudence of the United Nations Human Rights Committee. New York City: Routledge, 2013. 
COWEN, Denis Victor. The Foundations of Freedom: With Special Reference to Africa. Cape Town, South Africa: Oxford University Press, 1961.

CROWDER, Michael. Senegal: A Study in French Assimilation Policy. New York City: Taylor \& Francis, 1962.

CROWDER, Michael. Indirect Rule: French and British Style. Africa: Journal of the International African Institute, 1964, vol. 34, no. 3, pp. 197-205.

CROWDER, Michael. West Africa under Colonial Rule. Evanston, Illinois: Northwestern University Press, 1968.

CROWDER, Michael. Colonial West Africa: Collected Essays. New York City: Routledge, 1978.

CRUDEN, Alex, BRYFONSKI, Dedria. The End of Apartheid. Farmington Hills, Michigan: Greenhaven Press/Gale Cangage Learning, 2010.

DeLANCEY, Mark Dike, MBUH, Rebecca Neh, DELANCEY, Mark W. Historical Dictionary of the Republic of Cameroon. Lanham, Maryland: The Scarecrow Press, Inc., 2010.

DeROCHE, Andy. Kenneth Kaunda, the United States and Southern Africa. New York City: Bloomsbury Publishing, 2016.

DERRICK, Jonathan. The "Native Clerk" in Colonial West Africa. African Affairs, 1983, vol. 82 , no. 326 , pp. $61-74$.

DERSSO, Solomon (ed.). Perspectives on the Rights of Minorities and Indigenous Peoples in Africa. Pretoria, South Africa: Pretoria University Law Press, 2010.

DORMAN, Sara, HAMMETT, Daniel, NUGENT, Paul (eds.). Making Nations, Creating Strangers: States and Citizenship in Africa. Leiden, The Netherlands: Brill, 2007.

DOXEY, George V. The Industrial Color Bar in South Africa. Westport, Connecticut: Greenwood.

DUBOW, Saul. Apartheid, 1948-1994. Cape Town, South Africa: Oxford University Press, 2014.

EBRAHIM, Hassen. The Soul of a Nation: Constitution-Making in South Africa. Cape Town, South Africa: Oxford University Press, 1998.

EBUNE, Joseph B. The Dilemma of the Federal System in West Cameroon, 1961-1972. Journal of Scientific Research and Studies, 2016, vol. 3, no. 7, pp. 133-145. [online]. Available at: http://www.modernrespub.org/jsrs/pdf/2016/July/Ebune.pdf Accessed: 22 August 2017.

EGERÖ, Bertil. South Africa's Bantustans: From Dumping Grounds to Battlefronts. Uppsala: Nordiska Afrikainstitutet, 1991.

EGERTON, Hugh E. Colonies and the Mercantile System. In NADEL, George H., CURTIS, Perry (eds.). Imperialism and Colonialism. London, UK: Macmillan, 1969, pp. $57-66$.

ENONCHONG, Henry Ndifor Abi. Cameroon Constitutional Law: Federalism in a Mixed Common-Law and Civil-Law System. Yaoundé, Cameroon: Centre dédition et de production de manuels et d'auxilaires de l'enseignment, 1967.

ETEFA, Tsega. Integration and Peace in East Africa: A History of the Oromo Nation. New York City: Palgrave Macmillan, 2012.

EWUMBUE-MONONO, Churchill. Indigenous Minorities and the Future of Good Governance in Cameroon: An Inquiry into the Politics of Local Governance in the Local Councils of Fako Division, 1866-2001. Buea, Cameroon: Center for Researc h in Democracy and Development in Africa, 2001.

FALOLA, Toyin. AKINYEMI, Akintunde (eds.). Encyclopedia of the Yoruba. Bloomington, Indiana: Indiana University Press, 2016. 
FARAH, Douglas. Candidates Disqualified in Ivory Coast. The Washington Post, 7 October 2000. [online]. Available at: <https://www.washingtonpost.com/archive/politics/2000/10/07/candidates-disqualified-in-ivory-coast/2cb35bf1-6647-473c-af3d1441d6ab9172/?utm_term=.956be3136b55> Accessed: 23 November 2016.

FATTON, Robert, Jr. Liberal Democracy in Africa. Political Science Quarterly, 1990, vol. 105 , no. 3, pp. 455-473.

FISCHNER-TINÉ, Harald, MANN, Michael (eds.). Colonialism as Civilizing Mission: Cultural Ideology in British India. London: Wimbledon Publishing Company.

FORSYTHE, David P. (ed.). The United States and Human Rights: Looking Inward and Outward. Omaha, Nebraska: The University of Nebraska Press, 2000.

FREDRICKSON, George M. White Supremacy: A Comparative Study in American and South African History. Oxford, UK: Oxford University Press.

FRINDÉTHIÉ, K. Martial. From Lumumba to Gbagbo: Africa in the Eddy of the EuroAmerican Quest for Exceptionalism. Jefferson, North Carolina: McFarland \& Company, 2016.

GARANG, John. The Genius of Dr. John Garang: Speeches on the Comprehensive Peace Agreement (CPA). New York City: CreateSpace Independent Publishing Platform, 2015.

GHANEA, Nazila, XANTHAKI, Alexandra (eds.). Minorities, Peoples and Self-Determination: Essays in Honor of Patrick Thornberry. Leiden, The Netherlands: Brill, 2005.

GIFFORD, P., LOUIS, William R. (eds.). France and Britain in Africa: Imperial Rivalry and Colonial Rule. New Haven, Connecticut: Yale University Press, 1971.

GLOPPEN, Siri. South Africa: The Battle Over the Constitution. Aldershot, UK: Ashgate/ Dartmouth, 1997.

GOLDSTONE, Lawrence. Inherently Unequal: The Betrayal of Equal Rights by the Supreme Court, 1865-1903. New York City: Bloomsbury Publishing, 2011.

GOVERNMENT OF SOUTH AFRICA. Bophuthatswana at Independence: 6 December 1977. Pretoria, South Africa: Bureau for Economic Research re Bantu Development, 1977.

GOVERNMENT OF SOUTH AFRICA. The Interim South African Constitution 1993. [online]. Available at: <http://www.sahistory.org.za/article/interim-south-africanconstitution-1993> Accessed: 1 December 2016.

GRAWERT, Elke (ed.). After the Comprehensive Peace Agreement in Sudan. Suffolk, UK: James Currey, 2010.

GRILLO, Ralph, et al. (eds.). Legal Practice and Cultural Diversity. New York City: Routledge, 2009.

HALBROOK, Stephen P. Freedmen, The Fourteenth Amendment and the Right to Bear Arms, 1866-1876. Westport, Connecticut: Praeger, 1998.

HELLWEG, Joseph. Hunting the Ethical State: The Benkadi Movement of Côte d'Ivoire. Chicago, Illinois: The University of Chicago Press, 2011.

HUMAN RIGHTS WATCH. Côte d'Ivoire: The New Racism, The Political Manipulation of Ethnicity in Côte d'Ivoire. New York City: Human Rights Watch, 2001.

HUNTER, Guy (ed.). Industrialization and Race Relations: A Symposium. Westport, Connecticut: Greenwood, 1965.

HUTT, William H. The Economics of the Color Bar. London, UK: Institute of Economic Affairs, 1964.

IGWE, Obasi. Nigeria: The New Socialist Manifesto: With Some Lessons for Other African and Third World Countries. Lagos, Nigeria: Emancipation Press, 1989. 
ISIN, Engin F., NYERS, Peter (eds.). Routledge Handbook of Global Citizenship Studies. New York City: Routledge, 2014.

JOHNSON, Hilde F. South Sudan: The Untold Story from Independence to the Civil War. New York City: I. B. Tauris \& Co. Limited, 2016.

JOHNSON, Willard R. The Cameroon Federation: Political Integration in a Fragmentary Society. Princeton, New Jersey: Princeton University Press, 2015.

JOSEPH, Richard A. Radical Nationalism in Cameroun: Social Origins of the U.P.C. Rebellion. London, UK: Clarendon Press, 1977.

JUDSON, Karen. The Constitution of the United States. Berkeley Heights, New Jersey: Enslow Publishers, Inc. 2013.

KEFALE, Asnake. Federalism and Ethnic Conflict in Ethiopia: A Comparative Regional Study. New York City: Routledge, 2013.

KENDHAMMER, B. Muslims Talking Politics: Framing Islam, Democracy, and Law in Northern Nigeria. Chicago, Illinois: The University of Chicago Press, 2016.

KIMENYI, Mwangi S. Ethnic Diversity, Liberty and the State: The African Dilemma. Cheltenham, UK: Edward Elgar, 1997.

KOHN, Sebastian. Abusing Citizenship in Zambia-Again. Voices, Open Society Foundation. [online]. Available at: $<$ https://www.opensocietyfoundations.org/voices/abusing-citizenship-zambia-again> Accessed: 23 November 2016.

KONINGS, Piet, NYAMNJOH, Francis B. Negotiating an Anglophone Identity: A Study of the Politics of Recognition and Representation in Cameroon. Leiden, The Netherlands: Brill, 2003.

KROPF, Martha E. Institutions and the Right to Vote in America. New York City: Palgrave Macmillan, 2016.

KYMLICKA, Will. Three Forms of Group-Differentiated Citizenship in Canada. In BENHABIB, Seyla (ed.). Democracy and Difference: Contesting Boundaries of the Political. Princeton, New Jersey: Princeton University Press, pp. 153-170.

LAHIFF, Edward. An Apartheid Oasis? Agricultural and Rural Society: The Ciskei Xhosa and the Making of South Africa. Madison, Wisconsin: The University of Wisconsin, 1993.

LARAMONT, Ricardo R. Islamic Law and Politics in Northern Nigeria. Trenton, New Jersey: Africa World Press, 2011.

LeRICHE, Matthew, ARNOLD, Matthew. South Sudan: From Revolution to Independence. Oxford, UK: Oxford University Press, 2013.

LeVine, Victor T. The Cameroons: From Mandate to Independence. Berkeley and Los Angeles: The University of California Press, 1964.

LeVine, Victor T. Politics in Francophone Africa. Boulder, Colorado: Lynne Rienner, 2004.

LOUMPET-GALITZINE, Alexandra. Njoya et le Royaume Bamoun: Les Archives de la Société des Missions Évangéliques de Paris, 1917-1937. Paris: Éditions Karthala, 2006.

LOWENBERG, Anton D., KAEMPFER, William H. The Origins and Demise of South African Apartheid: A Public Choice Analysis. Ann Arbor, Michigan: The University of Michigan Press, 1998.

LUGARD, Lord Frederick. The Dual Mandate in Tropical Africa, 3d ed. London, UK: W. Blackwood and Sons, 1926.

MACLVER, Don (ed.). The Politics of Multinational States. New York City: Palgrave Macmillan, 2016.

MAGUBANE, Bernard M. The Political Economy of Race and Class in South Africa. New York City: Monthly Review Press, 1979. 
MAMDANI, Mahmood. Citizen and Subject: Contemporary Africa and the Legacy of Late Colonialism. Princeton, New Jersey: Princeton University Press.

MANBY, Bronwen. Citizenship Law in Africa: A Comparative Study. New York City: Open Society Foundations/African Minds, 2016.

MANDELA, Nelson. I am Prepared to Die: Nelson Mandela's Statement at the Opening of the Defense Case in the Rivonia Trial, Pretoria Supreme Court, April 20, 1964. [online]. Available at: <http://www.historyplace.com/speeches/mandela.htm> Accessed: 30 November 2016.

MANIÈRE, Laurent. Le Code de l'Indigénat en Afrique occidentale française et son Application: le Cas du Dahomey (1887-1946). Paris: Thèse, Université Paris Diderot, 2007.

MANN, Gregory. From Empires to NGOs in the West African Sahel: The Road to Nongovermentality. Cambridge, UK: Cambridge University Press, 2015.

MATTHEWS, Robert O., PRATT, Cranford (eds.). Human Rights in Canadian Foreign Policy. Kingston, Ontario \& Montreal, Quebec: McGill-Queen's University Press, 1988.

MBAKU, John Mukum. Property Rights and Rent Seeking in South Africa. Cato Journal, 1991, vol. 11, no. 1, pp. 135-150.

MBAKU, John Mukum. Institution and Reform in Africa: The Public Choice Perspective. Westport, Connecticut: Praeger, 1997.

MBAKU, John Mukum. Cameroon's Stalled Transition to Democratic Governance: Lessons from Africa's New Democrats. African and Asian Studies, 2002, vol. 1, no. 3, pp. $125-163$.

MBAKU, John Mukum. Constitutionalism and the Transition to Democratic Governance in Africa. In MBAKU, John Mukum, IHONVBERE, Julius O. (eds.). The Transition to Democratic Governance in Africa: The Continuing Struggle. Westport, Connecticut: Praeger, 2003, pp. 103-136.

MBAKU, John Mukum. Institutions and Development in Africa. Westport, Connecticut: Praeger, 2004.

MBAKU, John Mukum. Culture and Customs of Cameroon. Westport, Connecticut: Greenwood, 2005.

MBAKU, John Mukum. Constitutionalism and Governance in Africa. In KALU, Kelechi A., SOYINKA-AIREWELE, Peyi (eds.). Socio-Political Scaffolding and the Construction of Change: Constitutionalism and Democratic Governance in Africa. Trenton, New Jersey: African World Press, 2009, pp. 35-57.

MBAKU, John Mukum. What Should Africans Expect from their Constitutions? Denver Journal of International Law \& Policy, 2013, Vol. 41, No. 2, pp. 149-183.

MBAKU, John Mukum. Providing a Foundation for Wealth Creation and Development in Africa: The Role of the Rule of Law. Brooklyn Journal of International Law, 2013, vol. 38, no. 3, pp. 959-1051.

MBAKU, John Mukum. Judicial Independence, Constitutionalism and Governance in Cameroon: Lessons from French Constitutional Practice. European Journal of Comparative Law and Governance, 2014, vol. 1, no. 4, pp. 357-391.

MBAKU, John Mukum. Cameroon, Republic of (République du Cameroun). In FALOLA, Toyin, JEAN-JACQUES, Daniel (eds.), Africa: An Encyclopedia of Culture and Society. San Francisco, California: ABC-CLIO, 2015, pp. 139-177.

MBAKU, John Mukum, IHOVBERE, Julius O. Introduction: Issues in Africa's "New" Global Era. In MBAKU, John Mukum, IHONVBERE, Julius O. (eds.). Transition to Democratic Governance in Africa: The Continuing Struggle. Westport, Connecticut: 
Praeger, 2003, pp. 1-32.

MBAKU, John Mukum, KIMENYI, Mwangi S. Rent Seeking and Policing in Colonial Africa. The Indian Journal of Social Science, 1995, vol. 8, no. 3, pp. 277-306.

MBANASO, Michael U., KORIEH, Chima J. (eds.). Minorities and the State in Africa. Amherst, New York: Cambria, 2010.

MBOM, Sixtus. New Anti-Terrorism Law Batters Cameroonians Seeking Secession. Inter Press Service News Agency, April 26, 2015. [online]. Available at: <http://www. ipsnews.net/2015/04/new-anti-terrorism-law-batters-cameroonians-seeking-secession/> Accessed: September 9, 2017.

MENDY, Peter Karibe, LOBBAN, Richard A., Jr. Historical Dictionary of the Republic of Guinea-Bissau, 4th ed. Lanham, Maryland: Scarecrow Press, Inc., 2013.

MNGOMEZULU, B. Richard (eds.). The President for Life Pandemic in Africa: Kenya, Zimbabwe, Nigeria, Zambia and Malawi. London, UK: Adonis \& Abbey Publishers, Limited, 2013.

MOLTCHANOVA, Anna. National Self-Determination and Justice in Multinational States. New York City: Springer, 2009.

MOMOH, H. B. The Nigerian Civil War, 1967-1970: History and Reminiscences. London, UK: Sam Bookman Publishers, 2000.

MUKWENA, Royson, SUMAILI, Fanuel (eds.). Zambia at Fifty Years: What Went Right, What Went Wrong and Wither To? A Treatise of the Country's Socio-Economic and Political Developments Since Independence. Gurgaon, India: Partridge Publishing, 2016.

NATTRASS, Jill. The South African Economy: Its Growth and Change. Cape Town, South Africa: Oxford University Press.

NDI, Anthony. Southern West Cameroon Revisited (1950-1972) Vol. 1: Unveiling Inescapable Traps. Bamenda, Cameroon: Langaa Research \& Publishing CIG, 2014.

NFOR, Nfor N. In Chains for My Country: Crusading for the British Southern Cameroons. Bamenda, Cameroon: Langaa Research \& Publishing CIG, 2014.

NGOH, Victor Julius. History of Cameroon since 1800. Limbe, Cameroon: Presbook, 1996.

NGOH, Victor Julius. Cameroon: From Federal to Unitary State, 1961-1972. Limbe, Cameroon: Design House, 2004.

NORGREN, Jill, NANDA, Serena. American Cultural Pluralism and Law. Westport, Connecticut: Praeger, 2006.

OAKES, James. Freedom National: The Destruction of Slavery in the United States, 18611865. New York City: W. W. Norton and Company, Inc., 2013.

ODURUKWE, Ikechukwu. A New Dawn, Biafra, Our Right to Self-Determination, Freedom and the Future. Bloomington, Indiana: AuthorHouse, 2010.

OLSON, Mancur. The Rise and Decline of Nations: Economic Growth, Stagflation, and Social Rigidities. New Haven, Connecticut: Yale University Press, 1982.

OYEBADE, Adebayo (ed.). The Foundations of Nigeria: Essays in Honor of Toyin Falola. Trenton, New Jersey: Africa World Press, 2003.

PALMER, Vernon Valentine (ed.). Mixed Jurisdictions Worldwide: The Third Legal Family. Cambridge, UK: Cambridge University Press, 2012.

PAKENHAM, Thomas. The Scramble for Africa. Boston, Massachusetts: Little, Brown, 2015.

PARLIAMENT OF SOUTH AFRICA. Population Registration Act No. 30 of 1950. [online]. Available at: <https://www.thoughtco.com/population-registration-act-43473> Accessed: 23 November 2016. 
PERCIVAL, John. The 1961 Cameroon Plebiscite: Choice or Betrayal. Bamenda, Cameroon: Langaa Research \& Publishing CIG, 2008.

PERES, Phyllis. Transculturation and Resistance in Lusophone African Narrative. Gainesville, Florida: University of Florida Press, 1997.

RAUSCHNING, Dietrich, WIESBROCK, Katja, LAILACH, Martin. Key Resolutions of the United Nations General Assembly 1946--1996. Cambridge, UK: Cambridge University Press, 1997.

ROBINS, Steven L. From Revolution to Rights in South Africa: Social Movements, NGOs \& Popular Politics after Apartheid. Suffolk, UK and Rochester, New York: James Currey, 2008.

ROLANDSEN, Øystein H., DALY, M. W. A History of South Sudan: From Slavery to Independence. Cambridge, UK: Cambridge University Press.

RUDIN, Harry Rudolph. Germans in the Cameroons, 1884-1914: A Study in Modern Imperialism. New Haven, Connecticut: Yale University Press, 1938.

SANCTON, Andrew, ZHENMING, Sacton (eds.). Citizen Participation at the Local Level in China and Canada. Boca Raton, Florida: CRC Press, 2015.

SARRAUT, Albert. La mise en valeur des colonies françaises. Paris: Payot, 1923.

SCHMIDT, Elizabeth. Cold War and Decolonization in Guinea, 1946-1958. Athens, Ohio: Ohio University Press, 2007.

SHWEDER, Richard, MINOW, Martha, MARKUS, Hazel Rose (eds.). Engaging Cultural Differences: The Multicultural Challenge in Liberal Democracies. New York City: Russell Sage Foundation, 2002.

SEGAL, Lauren, CORT, Sharon. One Law, One Nation: The Making of the South African Constitution. Auckland Park, South Africa: Jacana Media (Pty) Ltd., 2011.

SHELLEY, Fred M. Nation Shapes: The Story Behind the World's Borders. San Francisco, California: BAC-CLIO, 2013.

SONNEBORN, Liz. The End of Apartheid in South Africa. New York: Chelsea House Publishers, 2010.

SOUTH AFRICAN DEMOCRACY EDUCATION TRUST. The Road to Democracy in South Africa, 1970-1980. South Africa Democracy Education Trust, 2004.

SOUTHALL, Roger. South Africa's Transkei: The Political Economy of an "Independent" Bantustan. New York: Monthly Review Press, 1983.

SPIES, S. B. The Origins of the Anglo-Boer War. London, UK: Edward Arnold, 1972.

STEPANEK, Joseph F. Wringing Success from Failure in Late-Developing Countries: Lessons from the Field. Westport, Connecticut: Praeger, 1999.

STRAND, Per. Decisions on Democracy: The Politics of Constitution-Making in South Africa, 1990-1996. Uppsala: Uppsala University Press, 2000.

SUBERU, Rotimi T. Ethnic Minority Conflicts and Governance in Nigeria. Nairobi, Kenya: Institut Français de Recherche en Afrique, 1999.

SWITZER, Les. Power and Resistance in an African Society: The Ciskei Xhosa and the Making of South Africa. Madison, Wisconsin: The University of Wisconsin Press, 1993.

TAIWO, Olufemi. Of Citizens and Citizenship. In AKIBÁ, Okon (ed.). Constitutionalism and Society in Africa. Aldershot, UK: Ashgate, 2004, pp. 55-78.

TAMES, Richard. The End of Apartheid: A New South Africa. London, UK: Heinemann Library, 2001.

TAMUNO, Tekena N. The Police in Modern Nigeria 1861-1965: Origins, Development and Role. Ibadan, Nigeria: The University of Ibadan Press, 1970.

THOMAS, C. H. Origin of the Anglo-Boer War Revealed, 2nd ed. Fairford, Glos, UK: Echo 
Library, 2006 [1900].

THOMPSON, Vincent Bakpetu. Conflict in the Horn of Africa: The Kenya-Somalia Border Problem 1941-2014. Lanham, Maryland: University Press of America, 2015.

THOMPSON, Virginia, ADLOFF, Richard. French West Africa. Stanford, California: Stanford University Press.

UNITED NATIONS. United Nations Visiting Mission to Trust Territories in West Africa: Report on Togoland under French Administration. New York City: United Nations, 1954.

UWECHUE, Ralph. Reflections on the Nigerian Civil War: A Call for Realism. London, UK: O.I.T.H. International Publishers Limited, 1969.

UZOKWE, Alfred Obiora. Surviving Biafra: The Story of the Nigerian Civil War: Over Two Million Died. Lincoln, Nebraska: iUniverse, 2003.

VORENBERG, Michael. Final Freedom: The Civil War, the Abolition of Slavery, and the Thirteenth Amendment. Cambridge, UK: Cambridge University Press, 2001.

WALDMEIR, Patti. Anatomy of a Miracle: The End of Apartheid and the Birth of the New South Africa. New Brunswick, New Jersey: Rutgers University Press, 1998.

WEDEMAN, Nicolas Blakely. Ethnicity and Territorial Conflict in Greater Somalia: Irredentism Reconsidered. Madison, Wisconsin: University of Wisconsin Press, 1989.

WEISBAND, Edward, OFFODILE, Chudi. The Politics of Biafra and the Future of Nigeria. Morrisville, North Carolina: Lulu Publishing Services, 2016.

WEISBAND, Edward, THOMAS, Courtney I. P. Political Culture and the Making of Modern Nation-States. New York City: Routledge, 2015.

WILKINSON, Michael (ed.). Global Pentecostal Movements: Migration, Mission, and Public Religion. Leiden, The Netherlands: Brill, 2012.

WILLIAMS, Walter E. South Africa's War Against Capitalism. Westport, Connecticut: Praeger.

YOUNG, Iris Marion. Justice and the Politics of Difference. Princeton, New Jersey: Princeton University Press, 1990. 